\title{
Speciation of naturally-accumulated uranium in an organic-rich soil of an alpine region (Switzerland)
}

\author{
Simona Regenspurg ${ }^{\mathrm{a}, \mathrm{b}, *, 1}$, Camille Margot-Roquier ${ }^{\mathrm{a}}$, Messaoud Harfouche ${ }^{\mathrm{b}}$, \\ Pascal Froidevaux ${ }^{\mathrm{c}}$, Philipp Steinmann ${ }^{\mathrm{c}, \mathrm{d}}$, Pilar Junier ${ }^{\mathrm{a}}$, Rizlan Bernier-Latmani ${ }^{\mathrm{a}}$ \\ a Environmental Microbiology Laboratory, Ecole Polytechnique Federale Lausanne, Switzerland \\ ${ }^{\mathrm{b}}$ Paul Scherrer Institute, Energy Research Development, Laboratory for Energy and Materials Cycles, Villigen, Switzerland \\ ${ }^{\mathrm{c}}$ University Institute of Radiation Physics, University Hospital Center, University of Lausanne, Lausanne, Switzerland \\ ${ }^{\mathrm{d}}$ Federal Office of Public Health, Consumer protection, Radioprotection, Schwarzenburgstrasse 165, 3001 Berne, Switzerland
}

Received 6 April 2009; accepted in revised form 21 December 2009; available online 13 January 2010

\begin{abstract}
Very high concentrations of uranium (up to $4000 \mathrm{ppm}$ ) were found in a natural soil in the Dischma valley, an alpine region in the Grisons canton in Switzerland. The goal of this study was to examine the redox state and the nature of uranium binding in the soil matrix in order to understand the accumulation mechanism. Pore water profiles collected from Dischma soil revealed the establishment of anoxic conditions with increasing soil depth. A combination of chemical extraction methods and spectroscopy was applied to characterize the redox state and binding environment of uranium in the soil. Bicarbonate extraction under anoxic conditions released most of the uranium indicating that uranium occurs predominantly in the hexavalent form. Surprisingly, the uranium redox state did not vary greatly as a function of depth. X-ray absorption near edge spectroscopy (XANES), confirmed that uranium was present as a mixture of U(VI) and U(IV) with U(VI) dominating. Sequential extractions of soil samples showed that the dissolution of solid organic matter resulted in the simultaneous release of the majority of the soil uranium content $(>95 \%)$. Extended X-ray absorption fine structure (EXAFS) spectroscopy also revealed that soil-associated uranium in the soil matrix was mainly octahedrally coordinated, with an average of 1.7 axial (at about $1.76 \AA$ ) and 4.6 to 5.3 equatorial oxygen atoms (at about $2.36 \AA$ ) indicating the dominance of a uranyl-like $\left(\mathrm{UO}_{2}{ }^{2+}\right)$ structure presumably mixed with some U(IV). An additional EXAFS signal (at about $3.2 \AA$ ) identified in some spectra suggested that uranium was also bound (via an oxygen atom) to a light element such as carbon, phosphorus or silicon. Gamma spectrometric measurements of soil profiles failed to identify uranium long-life daughter products in the soil which is an indication that uranium originates elsewhere and was transported to its current location by water. Finally, it was found that the release of uranium from the soil was significantly promoted at very low $\mathrm{pH}$ values $(\mathrm{pH} 2)$ and increased with increasing $\mathrm{pH}$ values (between $\mathrm{pH} 5$ and 9).
\end{abstract}

(C) 2010 Elsevier Ltd. All rights reserved.

\section{INTRODUCTION}

Natural uranium $(\mathrm{U})$ concentrations in soils uncontaminated by mining activities or the application of phosphate fertilizers typically range between 0 and 1.5 parts per million

\footnotetext{
* Corresponding author. Tel.: +49 03312881437.

E-mail address: regens@gfz-potsdam.de (S. Regenspurg).

1 Present address: Helmholtz Centre Potsdam, GFZ German Research Centre for Geosciences, Germany.
}

(ppm; Zielinski et al., 2006). Soil samples of the alpine Dischma valley (Grisons, Switzerland) were found to contain very high concentrations of $U$ (up to $4000 \mathrm{ppm} U$ ) raising questions about the processes responsible for this accumulation.

In natural settings, $\mathrm{U}$ occurs in the hexavalent (U(VI)) or tetravalent (U(IV)) oxidation states and forms a variety of minerals such as oxides or phosphate-, calcium-, silicatebearing minerals (Langmuir, 1978). U(IV), which is stable under anoxic conditions, commonly occurs as the poorly soluble mineral uraninite $\left(\mathrm{UO}_{2}\right)$. This mineral can form both 
under high pressure/temperature conditions (hence its common association with granitic rocks) and under atmospheric conditions by chemical or biological processes. U(VI), which typically occurs as the uranyl cation $\left(\mathrm{UO}_{2}{ }^{2+}\right)$, is more mobile relative to $\mathrm{U}(\mathrm{IV})$. The speciation of uranyl is strongly dependent on geochemical conditions. Below pH 5, the free cation typically dominates. In the presence of complexing anions, various U(VI) species such as carbonates, sulfates, and phosphates may form (Langmuir, 1978). At neutral to alkaline $\mathrm{pH}$ conditions, $\mathrm{U}(\mathrm{VI})$ can be retained in soil by adsorption to soil minerals or precipitation as U(VI) minerals such as uranyl hydroxide, or calcium uranyl phosphate (e.g., uranophane). Further, uranyl is known to complex readily with organic molecules such as acetate, oxalate or humic acid (Haas and Northup, 2004), which might explain why high U concentrations have been reported in humic-rich environments such as peats and bogs (e.g., Read et al., 1993; Owen and Otton, 1995; Gonzalez et al., 2006). This correlation results from the fact that the humic and fulvic acids, which are the main components of aqueous organic matter (OM), are efficient at exchanging protons with metals thereby forming aqueous complexes (Stumm and Morgan, 1996). However, the detailed study of uranium-humic or -fulvic acid complexes has not yielded structures due to the complexity of the organic compound despite the use of powerful techniques such as X-ray absorption spectroscopy (Schmeide et al., 2003). In addition, microbially-catalyzed reduction of metals in organic matter-rich environments was observed in which microorganisms use metals as terminal electron acceptors and the humic substances as donor or as an electron shuttle for anaerobic respiration (Lovley et al., 1996; Gu and Chen, 2003; Gu et al., 2005; Grybos et al., 2007; Wall and Krumholz, 2006). As a result of the inherent complexity of these systems, the underlying chemical processes responsible for $U$ accumulation in organic-rich soils are still poorly understood.

Naturally-occurring high $U$ concentrations in ground and surface water are documented in alpine regions (Owen and Otton, 1995; Deflorin, 2004) where the surrounding bedrock consists mainly of crystalline rocks that commonly contain trace amounts of U (Bernhard, 2005). Weathering processes mobilize $U$ from the rock and transport it to the pedosphere where it accumulates in the soil. However, no detailed characterization of the speciation of $U$ in these environments has ever been conducted, to our knowledge. The Swiss Dischma valley is unusual as a U-accumulating alpine environment in that the $U$ concentrations present at the site are sufficiently high to allow the spectroscopic study of U directly in the soil samples. The high concentrations of $U$ found at this site raise questions about what the mechanisms of the accumulation might be, if the uranium originated from a natural source and why the accumulation occurred in this particular area. An important key to answering these questions is to identify the speciation (re-

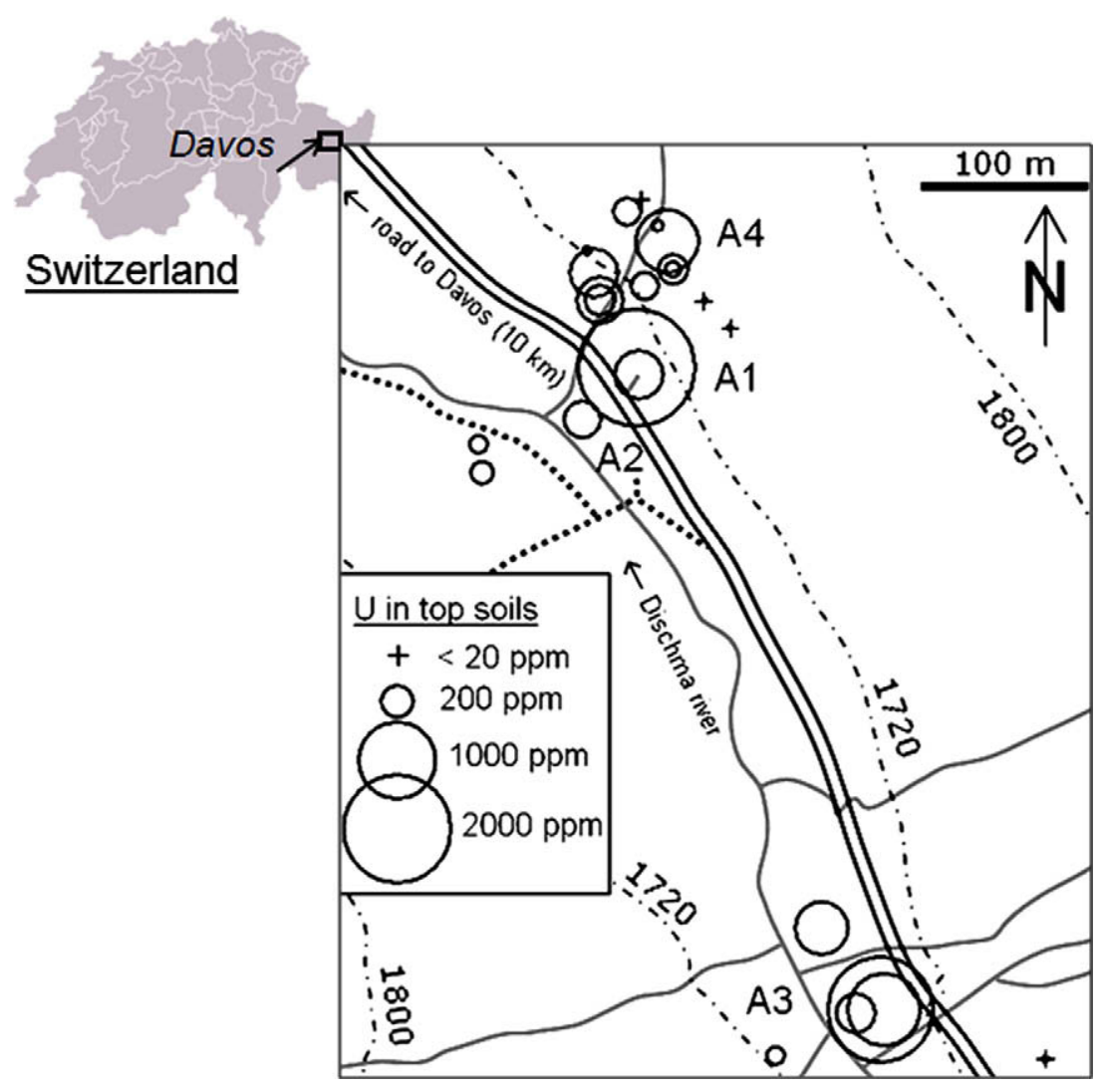

Fig. 1. Location of the four sampling areas (A1-A4) in the Dischma Valley, close to Davos (Grisons, Switzerland). Circles indicate the sample location with their areas being proportional to $U$ content. Overlapping circles of various diameters in the same vicinity reflect localized hotspots of $U$ and the variability in $U$ concentration as a function of location. 
dox state and chemical form) of $\mathrm{U}$ in the soil of the Dischma valley.

\section{MATERIALS AND METHODS}

\subsection{Sampling area}

The study area is located in the Dischma valley in the eastern part of the Swiss Alps about 10 kilometers southeast of Davos (Fig. 1). The formerly glaciated valley is about $15 \mathrm{~km}$ long and its floor rises from 1600 to $2000 \mathrm{~m}$. The crystalline bedrocks belong to the Upper Austroalpine Silvretta Nappe (mainly micaschists, amphibolites and gneisses). The crests rise from the floor to about $1000 \mathrm{~m}$ on either side of the valley through which the Dischma River flows. The floodplain is mostly covered by gravel and wet meadows whereas spruce forest and shrubs grow at higher altitudes. The soils investigated in this study are near-surface $(0-50 \mathrm{~cm}$ depth) organic-rich, water-saturated soils (histosols) of wetland sites (fens) or brown soils of alpine meadows.

\subsection{Sampling and sample preparation}

Samples of soil, surface water and pore water were collected during four sampling periods in October 2006, May 2007, October 2007 and July 2008. Two sampling strategies were used. First, a series of small soil cores (SC) or samples of soil surface were collected over the entire area of the valley (samples $\mathrm{SCa}-\mathrm{SCo}$ ) and in-situ gamma spectrometry measurements (see below) were obtained in order to conduct a survey of $U$ content across the valley. Second, four specific areas (A1-A4, Fig. 1) were targeted for more detailed sampling that included larger soil cores (labeled C1-C4 or E1-4), porewater (labeled PW1-4) and surface water, which was intended to help unravel the mechanism of $\mathrm{U}$ accumulation in the soil. Areas A1 (samples C1, PW1a,b,c, E1) and A3 (samples C3a, C3b and PW3) were characterized by high organic content and poor drainage but were not water saturated (they correspond to histosols) whereas A2 (sample PW2 and C2) was closer to the river and water saturated and A4 (sample E4) was higher up the slope in a brunisol area (Fig. 1). A map of sampling locations including GPS coordinates is presented in the supporting information (SI 1) of the electronic appendix.

The three types of soil samples collected were: (a) 15 small cores (SC) obtained by an Edelman drill with a diameter of $5 \mathrm{~cm}$, drilled to depths between 20 and $40 \mathrm{~cm}$; (b) four (large) soil cores $(\mathrm{C} 1, \mathrm{C} 2, \mathrm{C} 3 \mathrm{a}$ and $\mathrm{C} 3 \mathrm{~b}$; diameter of about $10 \mathrm{~cm} ; 30-60 \mathrm{~cm}$ deep) obtained with a peat soil corer (Buttler et al., 1998); (c) two cores (E1, E4) were obtained with an Eikelkamp corer (diameter $8 \mathrm{~cm}, 15 \mathrm{~cm}$ deep).

\subsubsection{Small and large core processing}

Immediately after extraction the cores $\mathrm{C} 1, \mathrm{C} 2, \mathrm{C} 3 \mathrm{a}$ and C3b were cut into 5-10 cm long slices and placed in Ziplock ${ }^{\mathrm{TM}}$ bags. This processing was performed under Ar gas flow to prevent potential oxidation of U(IV). The bags were flushed with Ar gas prior to sealing and cooled during the transport to the laboratory. Slicing (into five $10 \mathrm{~cm}$ - or eight $3-6 \mathrm{~cm}$ thick slices) and wet homogenization was carried out inside a glove box in a $\mathrm{N}_{2}$ atmosphere. Each slice was stored in a sealed jar under anoxic conditions. SC cores were split into equal size parts. Slices from $\mathrm{C} 1-\mathrm{C} 3 \mathrm{~b}$ and SC samples (ca. $100 \mathrm{~g}$ each) were dried in an oven at $105^{\circ} \mathrm{C}$ for $24 \mathrm{~h}$ and soil water content was determined by weighing before and after drying. Dried soil was homogenized by removing large roots and stones and ground up to a homogenous powder with a ceramic mortar and pestle. This powder was used for total digestion, sequential extraction, total organic carbon analysis and $\mathrm{U}$ analysis by gamma radiation. Dry SC samples were sieved to $<2 \mathrm{~mm}$ prior to analysis.

\subsubsection{Eikelkamp core processing}

Cores E1 and E4 were cut into $5 \mathrm{~cm}$ slices in the field and stored in plastic bags. In the laboratory samples were freeze-dried, milled, and the powder obtained was directly used for gamma spectrometry. A part of the sample was ashed at $550{ }^{\circ} \mathrm{C}$ and then digested for plutonium $(\mathrm{Pu}) /$ americium (Am)- or for $\mathrm{U}$ analyses by alpha spectrometry.

\subsubsection{Porewater sampling}

To characterize the composition of pore water as a function of depth, five pore water samplers ("peepers", Steinmann and Shotyk, 1997) were hammered into the soil down to a depth of about $50 \mathrm{~cm}$. The location of the pore water samplers (PW1a,b,c, PW2 and PW3) was close to the location of the collected core samples (C1,C2, C3a, C3b) (Fig. 1). The sampler consists of 20 compartments $(20 \mathrm{~mL}$ each) located every $2.5 \mathrm{~cm}$ with a membrane $(0.2 \mu \mathrm{m}$ pore size $)$ on either side allowing the diffusion of ions from the pore water into the compartment. The pore water sampler was filled with degassed and deionized water, placed into the soil and allowed to equilibrate for at least 3 weeks. Immediately upon retrieving the samplers, $10 \mathrm{~mL}$ from each compartment were collected with a syringe, filtered $(0.2 \mu \mathrm{m}$ polyethersulfone filter) and placed in a serum bottle and the bottle sealed. Both the syringe and the bottle were pre-purged with $\mathrm{N}_{2}$ to maintain anoxic conditions and avoid the oxidation of analytes. Another $3 \mathrm{~mL}$ were placed in a Falcon tube containing methanesulphonic acid (MSA) for the subsequent analysis of cations, and $500 \mu \mathrm{L}$ were put in a micro centrifuge tube containing $15 \mu \mathrm{L}$ of concentrated $\mathrm{HCl}$ for the subsequent analysis of ferrous iron. The $\mathrm{pH}$ was measured immediately (field $\mathrm{pH}$-meter) in the remaining pore water. Field dissolved oxygen measurements were attempted but were not accurate due to rapid equilibration with atmospheric $\mathrm{O}_{2}$.

Surface water samples were collected from mountain streams near the sampling areas and from Dischma River. All samples were transported to the laboratory cooled and were stored at $4{ }^{\circ} \mathrm{C}$ until further analysis.

\subsection{Analytical techniques}

Total concentration of $\mathrm{U}$, aluminum, phosphorus, iron, calcium and manganese as well as some heavy metals (arsenic, cadmium, cobalt, chromium, copper, nickel, lead and zinc) were measured by inductively coupled plasma optical emission spectroscopy (ICP-OES; Perkin Elmer, Plasma 2000), with detection limits ranging from 0.005 to $0.02 \mathrm{mg} / \mathrm{L}$. 
Uranium was also measured by gamma spectrometry with samples packed in a D5 $(40 \mathrm{~mL})$, SE $250(250 \mathrm{~mL})$ or well geometry $(5 \mathrm{~mL})$ with HPGe detectors calibrated using a multi-radio elements source (Saïdou et al., 2008). Uranium238 was determined via ${ }^{234} \mathrm{Th}(63 \mathrm{keV}$ line $)$ and ${ }^{234} \mathrm{~Pa}$ (1001 keV line) with good agreement between the two lines. Uranium-235 was quantified via its lines at $135 \mathrm{keV}$, $165 \mathrm{keV}$ and $205 \mathrm{keV}$. Radium-226 was obtained from the residual of the $186 \mathrm{keV}$ peak after subtraction of the ${ }^{235} \mathrm{U}$ contribution. Finally, ${ }^{231} \mathrm{~Pa}$, the long lived daughter of ${ }^{235} \mathrm{U}$, was determined by its line at $300 \mathrm{keV}$. The uncertainty of the gamma measurements was typically about $5 \%$.

Plutonium analyses included microwave digestion of the ashed soil samples, preconcentration of the actinides on a calcium-oxalate precipitate, microwave digestion of the oxalates, separation of $\mathrm{Pu}(\mathrm{IV})$ from trivalent cations on a Eichrom TEVA extraction resin and purification (elimination of $U$ and $T h$ ) on AG1x8 anion exchange resin. The final electrodeposition gave the counting sources for the alpha spectrometer (Canberra Alpha Analyst, PIPS detectors).

Uranium concentration in water and in highly diluted extracts from the sequential extraction was analyzed using a kinetic phosphorescence analyzer (KPA-11; Chemchek Instruments, Richland WA) which is specific for hexavalent $\mathrm{U}$ (uranyl) and has a detection limit of $5 \mathrm{nM} . \mathrm{HNO}_{3}$ was added to all samples (total concentration $0.1 \mathrm{M}$ ) to prevent $\mathrm{U}$ complexation with other solution anions. Total organic carbon content was measured in dried homogenized samples with a CASUMAT 8-ADGE TC analyzer (Wösthöff, Bochum, Germany), detection limit: $0.2 \mathrm{mg} / \mathrm{kg}$. TOC in extracts and aqueous solutions was analyzed with a Shimadzu TOC-Analyzer 5000, detection limit: $0.2 \mathrm{mg} / \mathrm{L}$.

Pore water anions $\left(\mathrm{NO}_{3}{ }^{-}, \mathrm{SO}_{4}{ }^{2-}, \mathrm{PO}_{4}{ }^{3-}, \mathrm{NO}_{2}{ }^{-}\right)$were measured on a Dionex DX 500 (Sunnyvale, CA) ion chromatograph with an IonPac AS12A column and a $30 \mathrm{mM}$ bicarbonate eluent, whereas cations $\left(\mathrm{NH}_{4}{ }^{+}, \mathrm{Na}^{+}, \mathrm{K}^{+}\right.$, $\mathrm{Mg}^{2+}, \mathrm{Ca}^{2+}$ ) were analyzed by with a Dionex ICS 3000 ion chromatograph, a CS16A column and a $30 \mathrm{mM}$ MSA eluent (Fritz and Gjerde, 2009).

Phosphate was additionally analyzed spectrophotometrically with a modified ascorbic acid method, based on Ames (1966) and standard methods (APWA, 1998). The reagent consists of a mixture of $1 \mathrm{~mL}$ of $100 \mathrm{mg} / \mathrm{L}$ ascorbic acid and $6 \mathrm{~mL}$ of $4.2 \mathrm{~g} / \mathrm{L}$ ammonium molybdate in sulfuric acid. The sample $(0.3 \mathrm{~mL})$ and reagent $(0.7 \mathrm{~mL})$ are incubated at $55^{\circ} \mathrm{C}$ for $10 \mathrm{~min}$ and the absorbance measured at $820 \mathrm{~nm}$ with a UV-2501 PC Shimadzu spectrophotometer.
Ferrous iron was determined using a colorimetric method described by Sørensen (1982) with ferrozine as complexing agent. A solution of ferrozine [3-(2-pyridyl)5,6-bis(4-phenylsulfonic acid)-1,2,4-triazine] was prepared at $1 \mathrm{~g} / \mathrm{L}$ in $50 \mathrm{mM}$ HEPES at $\mathrm{pH}$ 7.0. Anoxic acidified (pH 2) samples were analyzed for $\mathrm{Fe}(\mathrm{II})$ by mixing $15 \mu \mathrm{L}$ of sample with $1485 \mu \mathrm{L}$ of ferrozine solution. The absorbance at $562 \mathrm{~nm}$ was measured with a UV-2501 PC Shimadzu spectrophotometer.

\subsection{Sample characterization}

X-ray diffraction (XRD) analyses of different homogenized samples of $\mathrm{C} 1$ were carried out on powder with a SCINTAG XRD 2000 diffractometer based on methods described by Adatte et al. (1996).

Soil samples were dissolved completely using a three-step microwave digestion procedure developed for organic-rich sewage sludge by Lutz (2002) using a high performance microwave (Microwave Laboratory Systems). Briefly, $100 \mathrm{mg}$ of dried and homogenized sample were mixed first with $4 \mathrm{~mL}$ of $\mathrm{HNO}_{3}(65 \%)$ and $4 \mathrm{~mL}$ of $\mathrm{H}_{2} \mathrm{O}_{2}$ and the first microwave digestion step (all steps were carried out at $100{ }^{\circ} \mathrm{C}$ ) was started followed by the second, which involved the addition of $2 \mathrm{~mL}$ of $\mathrm{HF}(48 \%)$, and finally the third with the addition of $20 \mathrm{~mL}$ of $\mathrm{H}_{3} \mathrm{BO}_{3}(4.5 \%)$. The final extract was diluted with MilliQ water to $100 \mathrm{~mL}$ and analyzed for $\mathrm{U}$, As, $\mathrm{Cd}, \mathrm{Co}, \mathrm{Cr}, \mathrm{Cu}, \mathrm{Mn}, \mathrm{Ni}, \mathrm{Pd}, \mathrm{Zn}, \mathrm{Al}, \mathrm{P}, \mathrm{Fe}$ and $\mathrm{Ca}$.

\subsubsection{Sequential extraction}

Dried, homogenized powder from the various slices of core C3a was subjected to a sequential extraction method optimized for the quantification of actinides bound to an organic-rich soil (Schultz et al., 1998) to determine the soil fraction to which $U$ is bound. Additionally total $U$ was measured by complete digestion of the same samples as described above. All reaction steps were done in duplicates in a solution of $50 \mathrm{~mL}$. Table 1 summarizes the reactants and conditions for each step. The procedure was initiated with 2-g samples and after each extraction step, samples were centrifuged, supernatants filtered and solid residues were washed with $50 \mathrm{~mL}$ deionized water. In all filtrates and in the water wash $\mathrm{U}$ was measured by KPA.

\subsubsection{Uranium release}

The release of $U$ from a wet homogenized soil sample from core $\mathrm{C} 3 \mathrm{a}$ ( $2 \mathrm{~g}$ from a depth of $17 \mathrm{~cm}$ in a $30 \mathrm{~mL}$ suspension) was investigated in the presence of oxygen as a

Table 1

Sequential extraction procedure applied for each $2 \mathrm{~g}$ (dry weight) sample in $50 \mathrm{~mL}$ reactant (Schultz et al., 1998).

\begin{tabular}{llll}
\hline Step & Soil fractions & Used reactant & Procedure \\
\hline 1 & Exchangable & $0.4 \mathrm{M} \mathrm{MgCl}_{2}$ & Shaken for 1 h; centrifuged at $8000 \mathrm{rpm}$ for 20 min \\
2 & Organic matter & $5-6 \% \mathrm{NaOCl}^{*}$ & See (1); the procedure was repeated 3 times \\
3 & Carbonate & $1 \mathrm{M} \mathrm{NaAc} \mathrm{in} 25 \%$ acetic acid & Shaken for 2 h; centrifuged at $8000 \mathrm{rpm}$ for 20 min \\
4 & Fe-/Mn-oxides & $0.04 \mathrm{M} \mathrm{NH} 2 \mathrm{OH} * \mathrm{HCl} ; \mathrm{pH} \mathrm{2}$ & shaken for 5h; centrifuged at $8000 \mathrm{rpm}$ for 20 min \\
5 & Total & $\mathrm{H}_{2} \mathrm{O}_{2}, \mathrm{HNO}_{3} \mathrm{HF}, \mathrm{H}_{3} \mathrm{BO}_{3}$ (concentrated forms) & Microwave digestion \\
\hline
\end{tabular}

* The high TOC content of the samples required several repetitions of the procedure (until the liquid phase was transparent and of the same color as the $\mathrm{NaOCl}$ ). 
Table 2

Standards prepared for XAS analysis. U(IV) standards were treated under completely anoxic conditions.

\begin{tabular}{lllll}
\hline & $\mathrm{U}(\mathrm{IV})$-humic acid & $\mathrm{U}(\mathrm{VI})$-humic acid & $\mathrm{U}(\mathrm{VI})$ adsorbed to smectite at pH 5 & Colloidal UO $_{2}$ \\
\hline U redox state & +4 & +6 & +6 & +4 \\
Preparation/origin & $\begin{array}{l}\text { Addition of U(IV) solution } \\
\text { a }\end{array}$ & $\begin{array}{l}\text { Addition of U(VI)Ac } \\
\text { to humic acid }\end{array}$ & $\begin{array}{l}\text { XAS experimental data as obtained } \\
\text { to humic acid }\end{array}$ & $\begin{array}{l}\text { from A. Scheinost, FZD } \\
\text { Phase }\end{array}$ \\
\hline
\end{tabular}

${ }^{\text {a }}$ Solid $\mathrm{UO}_{2}$, prepared by biogenic reduction of $\mathrm{U}(\mathrm{VI})$ acetate was dissolved in $10 \mathrm{M} \mathrm{HCl}$.

b Pahokee peat humic acid as obtained from IHSS (International Humic Substances Society) was dissolved in $\mathrm{N}_{2}$ purged MilliQ.

function of $\mathrm{pH}$. Each experiment was performed in triplicate. The soil was suspended in either MilliQ water (ad-

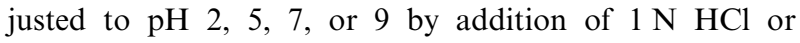
$\mathrm{NaOH})$ or in Dischma river water $(\mathrm{pH})$. Dischma water contained $0.7 \mu \mathrm{M} \mathrm{U}$ and trace levels of phosphate and $\mathrm{Fe}(\mathrm{II})$. All soil suspensions were placed on a shaker for 3 weeks. At time intervals, the $\mathrm{pH}$ was measured and subsamples $(2 \mathrm{~mL})$ of the suspension collected, filtered $(0.2 \mu \mathrm{m}$ polyethersulfone filter) and analyzed for U(VI) by KPA. Note that the solution obtained from the extraction at $\mathrm{pH}$ 9 is used for the dialysis experiments and XAS analysis as discussed below. Thus, it will be referred to subsequently.

\subsubsection{Bicarbonate extraction}

To quantify the U(VI) and U(IV) content in the soil, a bicarbonate extraction was performed under anoxic conditions as described by Zhou and Gu (2005) and Burgos et al. (2007). Wet homogenized soil samples at various depths from two cores $(\mathrm{C} 1$ and $\mathrm{C} 3 \mathrm{a})$ were split each into two parts. One part, $1.8 \mathrm{~g}$ (in $\mathrm{C} 1$ duplicates of soil) was handled in the anaerobic chamber $\left(95 \% \mathrm{~N}_{2} / 5 \% \mathrm{H}_{2}\right)$ and treated with anoxic $1 \mathrm{M}$ $\mathrm{NaHCO}_{3}$ in Falcon tubes. The samples were placed in a shaker and vigorously stirred for 1 week. Subsequently, the suspensions were filtered $(0.2 \mu \mathrm{m}$ polyethersulfone filter $)$ and the filtrate analyzed for U. Another fraction was subjected to microwave digestion as described above to obtain total $\mathrm{U}$ by ICP-OES. The amount of U(IV) present in the soil was obtained by difference between total $\mathrm{U}$ and $\mathrm{U}(\mathrm{VI})$.

\subsubsection{Dialysis to enrich aqueous uranium complexes}

The above-mentioned $\mathrm{pH} 9$ extract was a translucent, brownish solution containing high concentration of dissolved organic carbon. Natural organic matter $(\mathrm{OM})$ consists mainly of large molecular size (500-5000 Da) humic and fulvic acids (Stumm and Morgan, 1996). We sought to separate $\mathrm{U}$ bound to these large organic molecules from other (smaller-sized) forms of $U$ by a dialysis method. Two milliliters of the extract solution $(350 \mathrm{mg}$ TOC/L) were added with a needle into dialysis bags (slide-a-lyzer $2 \mathrm{kDa}$ molecular weight cut-off (MWCO) Dialysis Cassettes) placed into glass jars containing $500 \mathrm{~mL}$ of electrolyte $(0.1 \mathrm{M} \mathrm{NaCl})$. One subset was handled under oxic and the other under anoxic conditions (solutions were purged with $\mathrm{N}_{2}$ and stored in an anaerobic chamber). Since OM is known to have both oxidizing and reducing properties (Scott et al., 1998), the solutions were either purged with $\mathrm{H}_{2}$ for $1 \mathrm{~h}$ or $20 \mu \mathrm{L}$ of $0.01 \mathrm{M}$ dithionite $\left(\mathrm{Na}_{2} \mathrm{~S}_{2} \mathrm{O}_{4}\right)$, which is a strong reducing $\left(E_{0}=-666 \mathrm{mV}\right)$ agent was added to the $\mathrm{OM}\left(E_{0}=400-800 \mathrm{mV}\right.$; Blodau

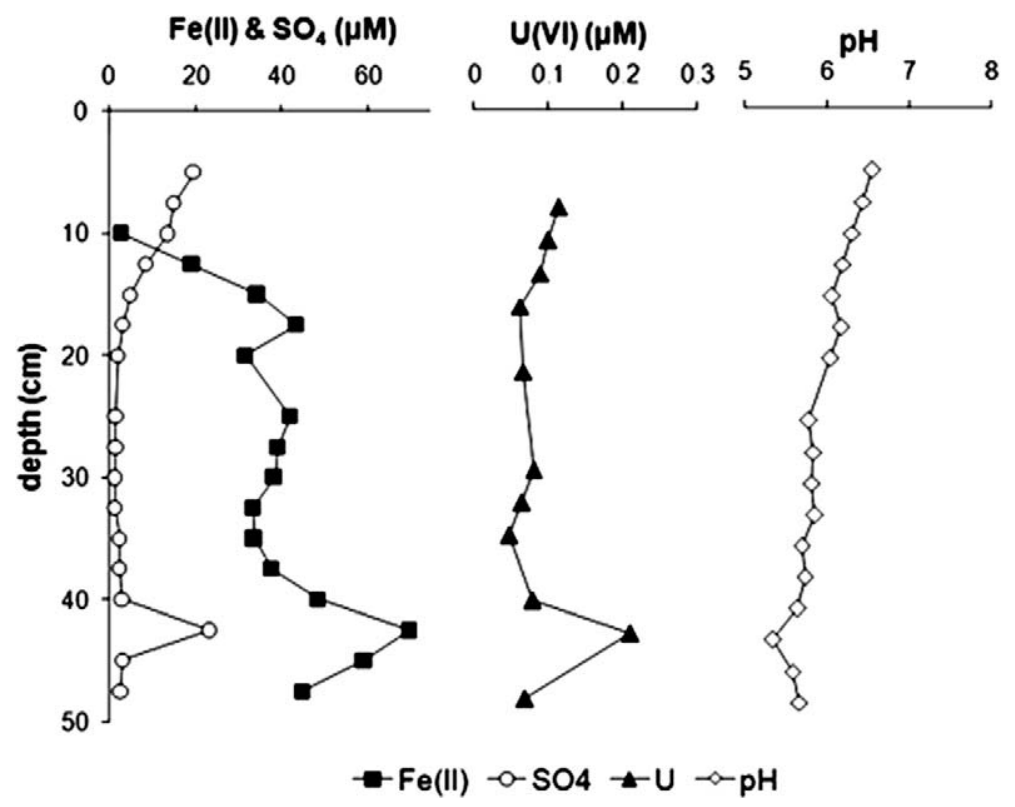

Fig. 2. Concentration profiles of Fe(II), sulfate, U(VI), and $\mathrm{pH}$ value over depth in the porewater sampler (PW 3). 
et al., 2009; Stuyk and Sposito, 2001) into the slide-a-lyzers. After 7 days, $20 \mu \mathrm{L} \mathrm{U}(\mathrm{VI})$ were added to obtain $0.1 \mathrm{mM}$ final concentration. After another week, a $500-\mu \mathrm{L}$ sample were removed from inside and outside the cassettes (for U analysis) and replaced by $500 \mu \mathrm{L}$ of bicarbonate $(0.25 \mathrm{mM}$ final concentration). Again after 1 week, samples were removed from inside and outside the slide-a-lyzers and analyzed for $\mathrm{U}$ and TOC.

\subsection{Synchrotron XAS measurements}

\subsubsection{Sample preparation}

Samples from core C3b, several synthetic standards and an oxic pH 9 extract from sample C3a $(17 \mathrm{~cm})$ (see U release experiment above) were prepared for XAS analysis: Core $\mathrm{C} 3 \mathrm{~b}$ was collected in the field, stored in a $\mathrm{N}_{2}$ flushed glovebox, and sliced and loaded onto sample holders within $30 \mathrm{~h}$ of collection. Samples in the holders were then stored in $\mathrm{N}_{2}$ filled air-tight jars, transported to the beamline and the measurements initiated within a day of preparation. No oxidation or beam damage was observed on a selected sample that underwent several XANES data collection in rapid succession (quick XANES). Standards and their preparation or origin are shown in Table 2.

\subsubsection{Measurements}

Uranium $\mathrm{L}_{\mathrm{III}}$-edge $(17,166 \mathrm{eV}) \mathrm{X}$-ray absorption spectra were collected at the superXAS beamline at the Swiss Light Source (SLS). The optics of the beamline consist of a watercooled $\mathrm{Si}(111)$ double crystal monochromator between two $\mathrm{Rh}$-coated mirrors; one for beam collimation and the other for focusing and rejection of higher order harmonics in the monochromatic beam. The energy of the monochromator was calibrated to K-edge of $\mathrm{Zr}$ metal foil $(17,998 \mathrm{eV})$. The EXAFS spectra were recorded in fluorescence mode using a 12-element Ge solid-state detector. Several scans were averaged to improve the signal-to-noise ratio for the EX-
AFS data (from $\sim 3$ scans (for references) to $\sim 8$ scans (for samples)). The collected EXAFS data were automatically deadtime-corrected during measurements.

\subsubsection{Data processing and evaluation}

Data reduction and processing were carried out using two software packages: IFEFFIT (Newville, 2001) and WinXAS (Ressler, 1998). After correction and background subtraction, the energy was converted to photoelectron vector wave units $\left(\AA^{-1}\right)$ by assigning the ionization energy of the $\mathrm{U} \mathrm{L}_{\mathrm{III}}$-edge, $E_{0}$, to the first inflection point of the absorption edge. The $\mathrm{k}^{3}$-weighted $\chi(\mathrm{k})$ functions were Fourier-transformed between 2 and $12 \AA^{-1}$ using a Bessel window function with a smoothing parameter of 4 . An $R$-range of $\sim 1-3 \AA$ was considered for data fitting. The amplitude reduction factor, $S_{0}^{2}$, was found to be 1.0 by fitting a $\mathrm{UO}_{2}$ standard measured at the same beamtime as the uranium samples. This parameter $\left(S_{0}^{2}\right)$ was, thus, held at this value (1.0) for all of the fits.

A multi-shell approach was employed for data fitting. Non-linear least square curve fitting was performed on the Fourier transforms (FTs). All single-scattering (SS) and multiple-scattering (MS) paths modeled in the fits were based on the theoretical model compounds $\left(\mathrm{UO}_{2}, \gamma-\mathrm{UO}_{3}, \mathrm{UO}_{2} \mathrm{CO}_{3}\right.$, $\mathrm{CaU}\left(\mathrm{PO}_{4}\right)_{2}, \quad \mathrm{Na}_{4}\left(\mathrm{UO}_{2}\right)\left(\mathrm{CO}_{3}\right)_{3}$ and $\left.\mathrm{Ca}\left(\mathrm{UO}_{2}\right)_{2}\left(\mathrm{SiO}_{3} \mathrm{OH}\right)_{2}\right)$ and derived from FEFF 8.0 (Rehr et al., 1991).

For the first shell, the coordination number $(\mathrm{CN})$, the parameter $\sigma^{2}$ of the Debye-Waller factor and the bond length $(R)$ were allowed to vary. In the fitting procedure, $S_{0}^{2}$ was fixed to the previously determined value of 1.0 and all other parameters [number of atoms $(N)$, inter-atomic distance $(R)$, parameter $\sigma^{2}$, and the energy shift $\left.\left(E_{0}\right)\right]$ were considered as variables to be determined. In the case of a split equatorial shell (observed only in the U(VI)-humic standard), $\sigma^{2}$ of the two shells were constrained to be the same value to avoid correlation problems between $N$ and $\sigma^{2}$. In the case where the data allow fitting intermediate- and long-range order, the MS

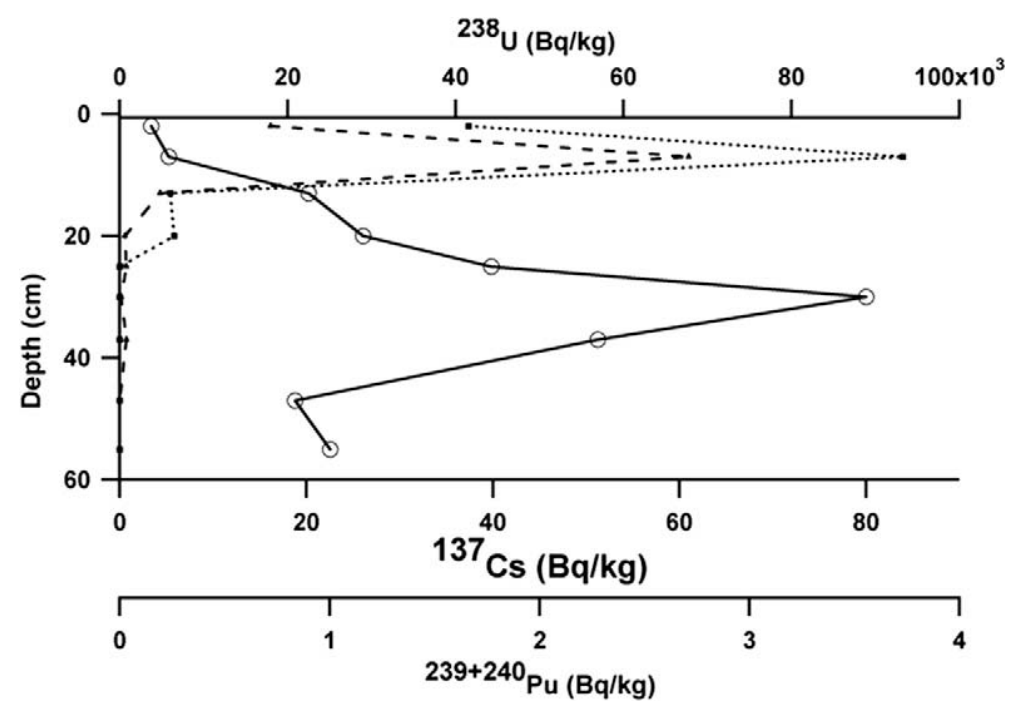

Fig. 3. Depth profile of the radio isotopes ${ }^{230+240} \mathrm{Pu}$ (dashed line), ${ }^{137} \mathrm{Cs}$ (dotted line) and ${ }^{238} \mathrm{U}$ (solid line) as measured in sample E1. The presence of the upper peaks $(0-15 \mathrm{~cm})$ of the ${ }^{137} \mathrm{Cs}$ and ${ }^{230+240} \mathrm{Pu}$ profiles, which reflect the nuclear fallout of the sixties (Pu activity) and the contribution of the Chernobyl accident $\left({ }^{137} \mathrm{Cs}\right.$ activity), indicate that the soil is undisturbed. 
path $\mathrm{U}-\mathrm{O}_{\mathrm{ax}}-\mathrm{U}-\mathrm{O}_{\mathrm{ax}}-\mathrm{U}\left(4\right.$ legged axial path at $\left.180^{\circ}\right)$ was included in the fits as described previously (Allen et al., 1996; Hudson et al., 1996). The shift in the threshold energy, $E_{0}$, was allowed to vary as a global parameter but was constrained to be the same value in the different shells.

A preliminary scan of micro XAS on the soil core sam-

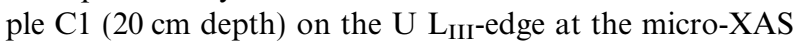
beamline at SLS was obtained with an incoming energy of $17.5 \mathrm{keV}$ and a beam size of $3 \mu \mathrm{m}$ (hor) $\times 2 \mu \mathrm{m}$ (vert). Pixel size was $3 \times 3 \mu \mathrm{m}$.

\section{RESULTS}

\subsection{Pore water composition}

The composition of the porewater as a function of depth was fairly uniform in the samples collected. A notable exception is sample PW3 for which many analytes, particularly the cations, showed a peak at a depth of $40-45 \mathrm{~cm}$ (see supporting information, SI 2). This suggests potential seepage of groundwater from below at that location. To summarize, concentrations of main compounds in all analyzed porewater samples, calcium $\left(\mathrm{Ca}^{2+}\right)$ ranged from 400 to $3000 \mu \mathrm{M}$ and potassium $\left(\mathrm{K}^{+}\right)$, which had a similar depth profile as $\mathrm{Ca}^{2+}$, ranged from 40 to $150 \mu \mathrm{M}$ with the exception for PW2 for which $\mathrm{K}^{+}$ranged from 200 to $600 \mu \mathrm{M}$. Sodium $\left(\mathrm{Na}^{+}\right)$concentrations ranged from 200 to $1000 \mu \mathrm{M}$ and there was little variability as a function of depth in each profile. Phosphate concentrations were low throughout the profiles as they ranged from 1 to $5 \mu \mathrm{M}$. pH values did not vary considerably as a function of depth and were near neutral for PW2 (pH 6.56.9). However, for $\mathrm{PW} 3$, the $\mathrm{pH}$ decreased from a value of 6.5 near the surface to a minimum of 5.3 at depth (Fig. 2). The organic carbon content (TOC) in the porewater was generally high (10 to $180 \mathrm{ppm}$ ) and varied strongly both within the profiles and as a function of location, without a clear trend. Overall, the concentration of $\mathrm{U}$ in porewater was low and ranged from 0.01 to $0.3 \mu \mathrm{M}$ (Fig. 2). There is a decrease in sulfate and an increase in $\mathrm{Fe}(\mathrm{II})$ with increasing depth whereas the concentration of $U$ remains relatively constant (Fig. 2). This result suggests that reducing conditions are established in the soil around $15 \mathrm{~cm}$ and below, which is consistent with the detection of sulfide in the deepest samples (data not shown). Interestingly, however, there is a clear transition at around $42 \mathrm{~cm}$ that is also visible in the data for other cations and anions (Fig. SI 2). We suggest that subsurface lateral seepage of (ground) water, rich in $\mathrm{Fe}(\mathrm{II}), \mathrm{SO}_{4}{ }^{2-}$, $\mathrm{U}(\mathrm{VI}), \mathrm{Ca}^{2+}, \mathrm{K}^{+} \cdot \mathrm{Cl}^{-}$and $\mathrm{PO}_{4}{ }^{3-}$ at a depth between 40 and $45 \mathrm{~cm}$ accounts for this phenomenon.

\subsection{Soil characterization}

The deeper soil cores investigated in this study are histosols of wetlands (fens). Additional samples of near-surface soils were taken from brown soils of alpine meadows or from dark brown to black organic-rich soils (histosols) of water-saturated spots within the alpine meadows over a large area of the valley (SI, Fig. 1).

\subsubsection{Soil composition}

Plutonium $\left({ }^{239+240} \mathrm{Pu}\right),{ }^{241} \mathrm{Am}$, and ${ }^{137} \mathrm{Cs}$ were measured in the soil profile of $\mathrm{E} 1$ to get an indication of whether the soil column has been disturbed. These artificial radioisotopes are of exclusive atmospheric origin and were introduced in the early 1960s as result of the fallout of atmospheric nuclear bomb tests and in 1986 following the Chernobyl reactor accident. Because of their historical origin, ${ }^{137} \mathrm{Cs}$ and $\mathrm{Pu}$ are used as indicators for whether a soil

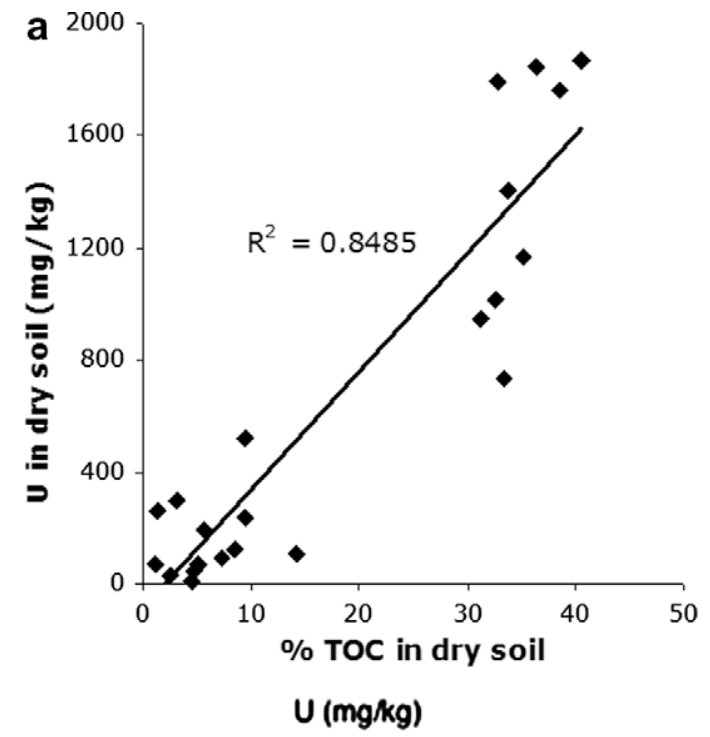

$\begin{array}{lllllllll}\text { b } & 0 & 50 & 100 & 150 & 200 & 250 & 300 & 350\end{array}$

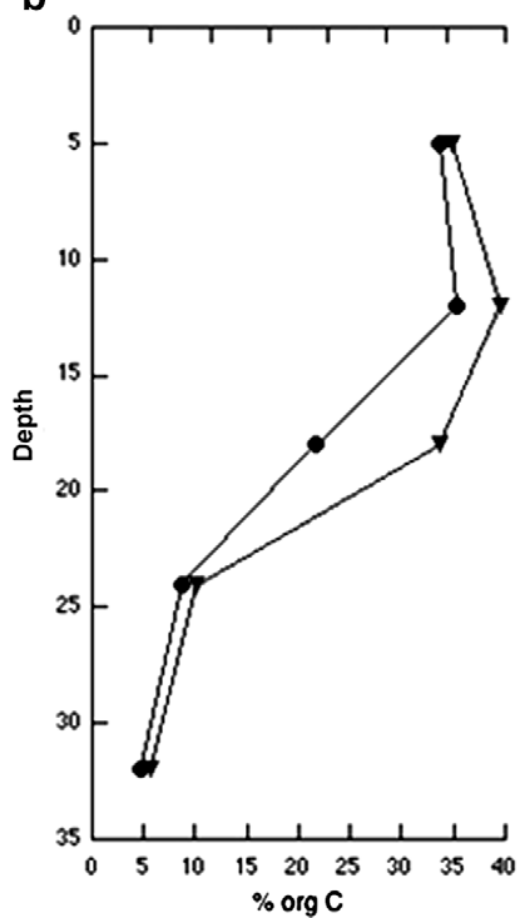

Fig. 4. Uranium and organic matter association. (a) Association between $U$ and TOC in 21 core samples collected along the Dischma valley (see map; SI Fig. 1). (b) Uranium (upside down filled triangle) and TOC (filled circle) content in the soil profile of core C3b. 


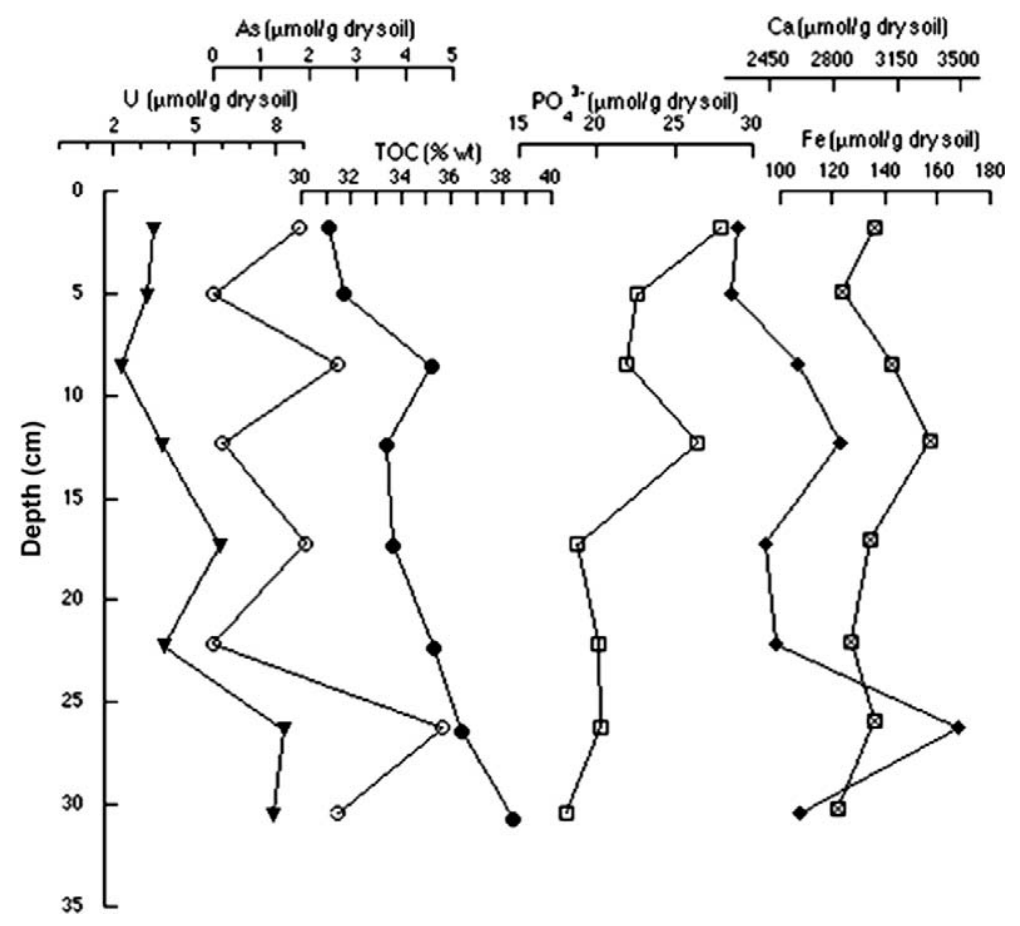

Fig. 5. Depth distribution of As (empty circle); $\mathrm{Ca}$ (filled diamond); $\mathrm{PO}_{4}$ (empty square), $\mathrm{Fe}$ (crossed square), U (upside down filled triangle), and TOC (filled circle) in core C3a.

has been mixed vertically. Both elements are strongly enriched in the Dischma soil at a depth of about $8 \mathrm{~cm}$ $\left(2.8 \mathrm{mBq} / \mathrm{g}\right.$ and $80.2 \mathrm{mBq} / \mathrm{g}$ of $\mathrm{Pu}$ and ${ }^{137} \mathrm{Cs}$, respectively) and decrease rapidly with increasing depth to reach the detection limit at a depth of $20 \mathrm{~cm}$ (Fig. 3). Additional ${ }^{137} \mathrm{Cs}$ measurements in soil profiles $\mathrm{C} 1$ and $\mathrm{C} 3 \mathrm{a}$ showed a similar pattern (data not shown). These results suggest that ${ }^{137} \mathrm{Cs}$ and $\mathrm{Pu}$ were introduced into the soil at a specific time and that the soil column has not been significantly disturbed by anthropogenic activities since. Gamma spectrometry of various radioactive compounds in core E1 $\left(27-32 \mathrm{~cm}\right.$ depth) gave the following results: ${ }^{238} \mathrm{U}$ (via ${ }^{234} \mathrm{Th} ; 63 \mathrm{keV}$ line): $88890 \mathrm{~Bq} / \mathrm{kg} ;{ }^{235} \mathrm{U}$ (134, 165, $205 \mathrm{keV}$ lines): $4319 \mathrm{~Bq} / \mathrm{kg} ;{ }^{234} \mathrm{U}$ (186 keV line): $4322 \mathrm{~Bq} /$ $\mathrm{kg} ;{ }^{226} \mathrm{Ra}\left(186 \mathrm{keV}\right.$ line; expressed in $\%$ of $\left.{ }^{238} \mathrm{U}\right):<1 \%$; ${ }^{231} \mathrm{~Pa}\left(300 \mathrm{keV}\right.$ line; expressed in $\%$ of $\left.{ }^{235} \mathrm{U}\right): 3.9 \%$. The U in the soils has a natural isotopic composition inasmuch the observed ratio of ${ }^{238} \mathrm{U} /{ }^{235} \mathrm{U}$ of $20.6(\mathrm{E} 1 ; 27-32 \mathrm{~cm}$ depth) is in agreement with the natural abundance of these two isotopes (ratio ${ }^{238} \mathrm{U} /{ }^{235} \mathrm{U}=21$ ). The virtual absence of ${ }^{238,235} \mathrm{U}$-daughter isotopes such as ${ }^{226} \mathrm{Ra}$ and ${ }^{231} \mathrm{~Pa}$ indicates that $\mathrm{U}$ has been transported to the Dischma soil relatively recently since we would expect the decay over geologic time to produce daughter isotopes in-situ.
A survey of the $U$ and TOC soil content across the valley shows that there is an association between the two parameters (Fig. 4a): high U content always corresponds to high organic matter content. Furthermore, the cores that were analyzed for both $\mathrm{U}$ and TOC as a function of depth show a clear correlation between $\mathrm{U}$ and TOC content (cores C3b and C3a in Figs. 4b and 5 , resp.) but no obvious correlation between $U$ and phosphate, $\mathrm{Ca}$ or Fe (Fig. 5). Moreover, the U and TOC distribution pattern varies even within one sampling area as the $\mathrm{U}$ and TOC content increases as a function of depth in one core $(\mathrm{C} 3 \mathrm{a})$ and decreases in another $(\mathrm{C} 3 \mathrm{~b})$ (Figs. $4 \mathrm{~b}$ and 5). Nonetheless, high $\mathrm{U}$ is consistently associated with high TOC content.

$\mathrm{U}$ concentrations in the soil range between 25 and $4000 \mathrm{ppm}$. Table 3 shows the concentration range of some elements in dried soil sample profiles of C2 and C3a. In addition to carbon, main elements in the soil, as measured by ICP-OES after total digestion of the core slices are $\mathrm{Ca}$, $\mathrm{Al}, \mathrm{Mg}$ and Fe (Table 3, Fig. 5). Silicon was not measured, but considering the local geology, expected to be a main component. A survey of main and trace elements over the profile of core $\mathrm{C} 3 \mathrm{a}$ are presented in the supporting information (SI 3) of the electronic annex.

Table 3

Range of selected elements in the soil cores $\mathrm{C} 2$ and C3a (metals measured by ICP; TOC by TOC analyser); data are in weight- $\%$ of dry mass.

\begin{tabular}{lllllll}
\hline Core & TOC & $\mathrm{Ca}$ & $\mathrm{Mg}$ & $\mathrm{Al}$ & $\mathrm{Fe}$ & $\mathrm{U}$ \\
\hline $\mathrm{C} 2$ & $\mathrm{~nm}$ & $3-11$ & $0.5-1.5$ & $2.4-4.5$ & $0.7-1.3$ & $0.1-0.4$ \\
$\mathrm{C} 3 \mathrm{a}$ & $31-38.5$ & $9-14$ & $1.3-2.4$ & $0.3-2.2$ & $0.7-0.8$ & $0.05-0.2$ \\
\hline
\end{tabular}

$\mathrm{nm}$, not measured. 


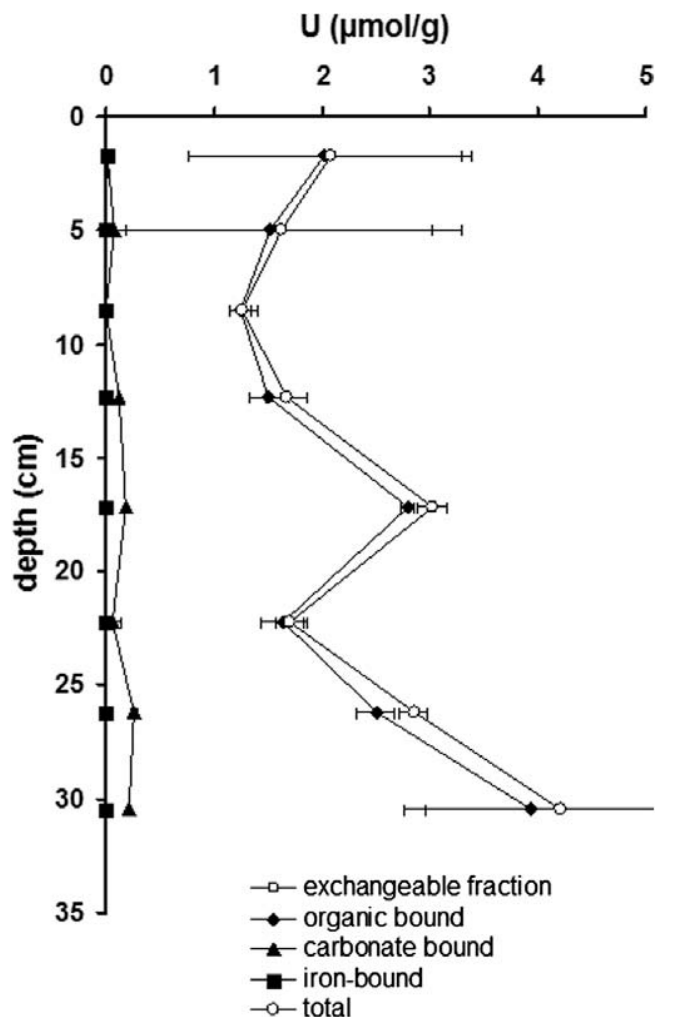

Fig. 6. Uranium release after sequential extraction of a soil core (C3a) as a function of depth. Extraction reagents/ steps are: $\mathrm{MgCl}_{2}$ (easily exchangeable $\mathrm{U}$ ), $\mathrm{NaOCl}$ (organic carbon-bound $\mathrm{U}$ ), $\mathrm{Na}$ acetate, (carbonate-bound $\mathrm{U}$ ), $\mathrm{NH}_{2} \mathrm{OH} * \mathrm{HCl}$ (U bound to $\mathrm{Fe}$ - and $\mathrm{Mn}$ oxides) and microwave digestion to dissolve the sample completely and determine total U. Error bars refer to range of duplicates.

XRD measurements (core $\mathrm{C} 1$; data not shown) revealed that the primary minerals present in the Dischma soil reflect what is typically found in similar carbonate-free, alpine environments: quartz, albite, plagioclase, microcline, micas (especially muscovite) and phyllosilicates.

\subsubsection{Soil extractions}

Sequential extraction of $U$ as a function of depth in core $\mathrm{C} 3 \mathrm{a}$ revealed that the majority of $\mathrm{U}(95-98 \%)$ is released when the sample is reacted with $\mathrm{NaOCl}$ (Fig. 6), which is thought to oxidatively dissolve the organic phase. Thus, this result suggests that $U$ is associated with organic matter in the Dischma soil. However, we cannot exclude the possibility that $\mathrm{NaOCl}$ oxidizes a reduced form of $\mathrm{U}$ and causes the release of $\mathrm{U}(\mathrm{VI})$ independently of organic matter. It is noteworthy that the first extraction step $-\mathrm{MgCl}_{2}$ under oxic conditions - did not oxidize and release $U$. Thus, if $U$ is present in its reduced state, it is stable enough to remain reduced under oxic conditions.

The stability of the $U$ bound to the soil was investigated under oxic conditions at various $\mathrm{pH}$ values (2-9). Uranium and TOC release along with $\mathrm{pH}$ were monitored over 21 days. The effect of $\mathrm{pH}$ on $\mathrm{U}$ and TOC release is evident from Fig. 7. Little $U$ release was observed following the equilibration of soil in oxic MilliQ water $(0.03 \mu \mathrm{mol} / \mathrm{g}$ soil $)$

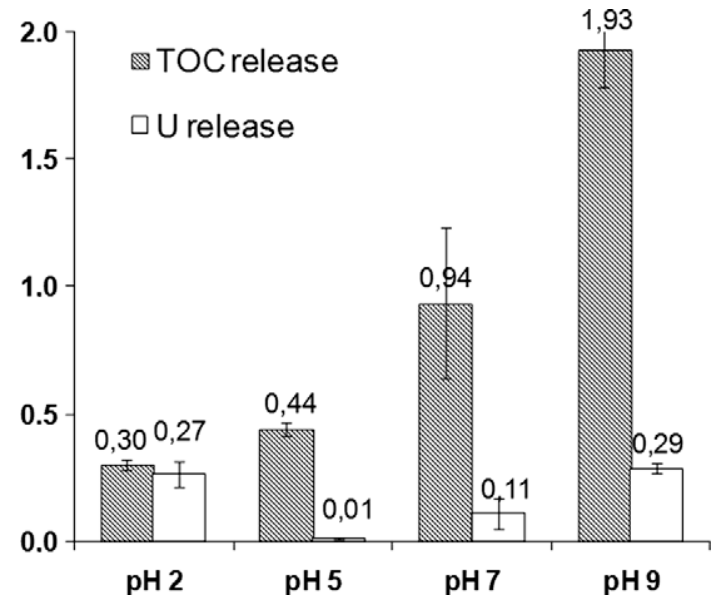

Fig. 7. Release of U and TOC from Dischma soil samples (C3a; $17 \mathrm{~cm}$ depth; mean values and standard deviation of triplicates) after 21 days of reaction with MilliQ water at oxic conditions at different $\mathrm{pH}$ values. Reference soil sample, to which solely MilliQ water was added, showed a $\mathrm{pH}$ of 6.5 and $0.02 \mathrm{mM} \mathrm{U}$ were released (data not shown).

after 21 days ( $\mathrm{pH} 6.5$ ) (data not shown). In the $\mathrm{pH}$ range of $5-9$, a direct correlation was observed between the equilibrium $\mathrm{pH}$ and the concentration of released $\mathrm{U}$ and TOC, inasmuch as at $\mathrm{pH} \mathrm{5,7}$ and 9, 0.44, 0.94 and $1.93 \mathrm{mmol}$ TOC/g soil and $0.01,0.11$ and $0.29 \mu \mathrm{mol} \mathrm{U/g}$ soil were released, respectively (Fig. 7). The rate of $U$ release is greatest initially ( $85 \%$ of total released by 4 days) but there is continuous release up until 21 days (data not shown). The correlation between released TOC and $\mathrm{U}$ was highly significant (Spearman's correlation: 0.97) for $\mathrm{pH}$ values 5, 7 and 9, suggesting that TOC and $U$ are released at the same time and thus are associated. In contrast, at lower $\mathrm{pH}$ values $(\mathrm{pH} 2), \mathrm{U}$ release is comparable to that at $\mathrm{pH} 9$ $(0.27 \mu \mathrm{mol} / \mathrm{g}$ vs. $0.29 \mu \mathrm{mol} / \mathrm{g})$ whereas the TOC release is relatively low. This indicates that, in the latter case, $\mathrm{U}$ is released from the solid phase without dissolution of organic matter - probably by a proton exchange reaction.

Finally, the mobilization of $U$ from a soil core (C3a) was tested using a bicarbonate solution $(1 \mathrm{M})$ under anoxic conditions. A large fraction $(51-100 \%)$ of the total $U$ in the samples was mobilized and thus presumably present as $\mathrm{U}(\mathrm{VI})$. The calculated difference between total $\mathrm{U}$ and anoxic bicarbonate-extracted U(VI) reveals that U(IV) content ranges between $0 \%$ and $49 \%$ with no correlation with depth and high variability in dependence of the location of core extraction (Fig. 8). Control samples from the same cores treated solely with MilliQ water under oxic and anoxic conditions released little $U(<0.1 \mu \mathrm{mol} / \mathrm{L}$; data not shown).

\subsubsection{Dialysis of soil extract}

The $\mathrm{pH} 9$ extract from a depth of $17 \mathrm{~cm}$ in core $\mathrm{C} 3 \mathrm{a}$ was dialyzed through a 2000 MWCO membrane to remove small molecules and trap the OM that was released from the soil. Two treatments were carried out in parallel: the extract was oxidized by equilibration with atmospheric $\mathrm{O}_{2}$ or reduced by $\mathrm{H}_{2}$ purging or dithionite amendment. Subse- 


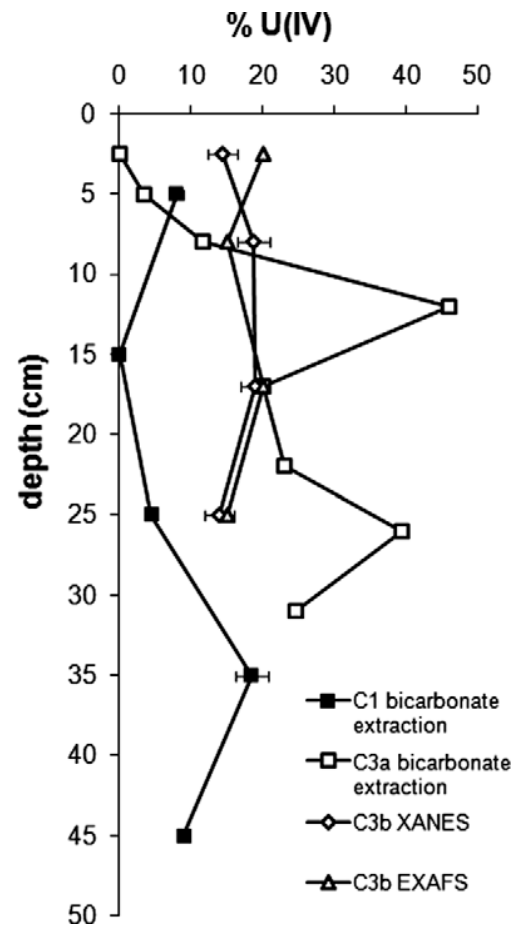

Fig. 8. Uranium(IV) percentage in different soil samples (core C1, $\mathrm{C} 3 \mathrm{a}, \mathrm{C} 3 \mathrm{~b}$ ) as a function of depth as determined by bicarbonate extraction (core $\mathrm{C} 1$, black squares) and $\mathrm{C} 3 \mathrm{a}$, white squares) and compared to data from XAS spectroscopy (core C3b) using XANES (white diamonds) and EXAFS (white triangles) data, respectively.

quently, U(VI) was added to the inside of the dialysis cassette. The results (Table 4 ) clearly show that $U$ is retained inside the dialysis cassette by association with organic matter ( $>80 \%$ of the initial) and strongly suggest that OM from Dischma soil has a high affinity for U(VI). A control with a humic acid reference retained within a dialysis cassette shows that the majority $(>97 \%)$ of $U$ diffuses out of the dialysis cassette until equivalent concentrations are reached inside and outside the cassettes (Table 4). Differences between oxic and anoxic treatments were not significant. The subsequent addition of bicarbonate $(0.1 \mathrm{M})$ into the

Table 4

Uranium concentrations $(\mu \mathrm{M})$ inside the dialysis cassettes before and after bicarbonate treatment in presence and absence of organic matter. The initially added $\mathrm{U}$ concentration was $100 \mu \mathrm{M}$ in the cassettes.

\begin{tabular}{|c|c|c|c|c|}
\hline \multirow[t]{2}{*}{$\mathrm{U}$ inside the cassettes } & \multicolumn{2}{|c|}{ Soil extract pH 9} & \multicolumn{2}{|c|}{$\begin{array}{l}\text { Humic acid-free } \\
\text { reference }\end{array}$} \\
\hline & Oxic & Anoxic $^{*}$ & Oxic & Anoxic $^{*}$ \\
\hline $\begin{array}{l}\text { Before } \mathrm{NaHCO}_{3} \\
\text { addition }\end{array}$ & $80.3 \pm 12.5$ & $85.9 \pm 7.6$ & 2.8 & 2.3 \\
\hline $\begin{array}{l}\text { After } \mathrm{NaHCO}_{3} \\
\text { addition }\end{array}$ & 14.05 & 13.38 & $\mathrm{~nm}$ & $\mathrm{~nm}$ \\
\hline
\end{tabular}

$\mathrm{nm}$, not measured

* Mean values from samples treated anoxic by addition of dithionite or by addition of $\mathrm{H}_{2}$.

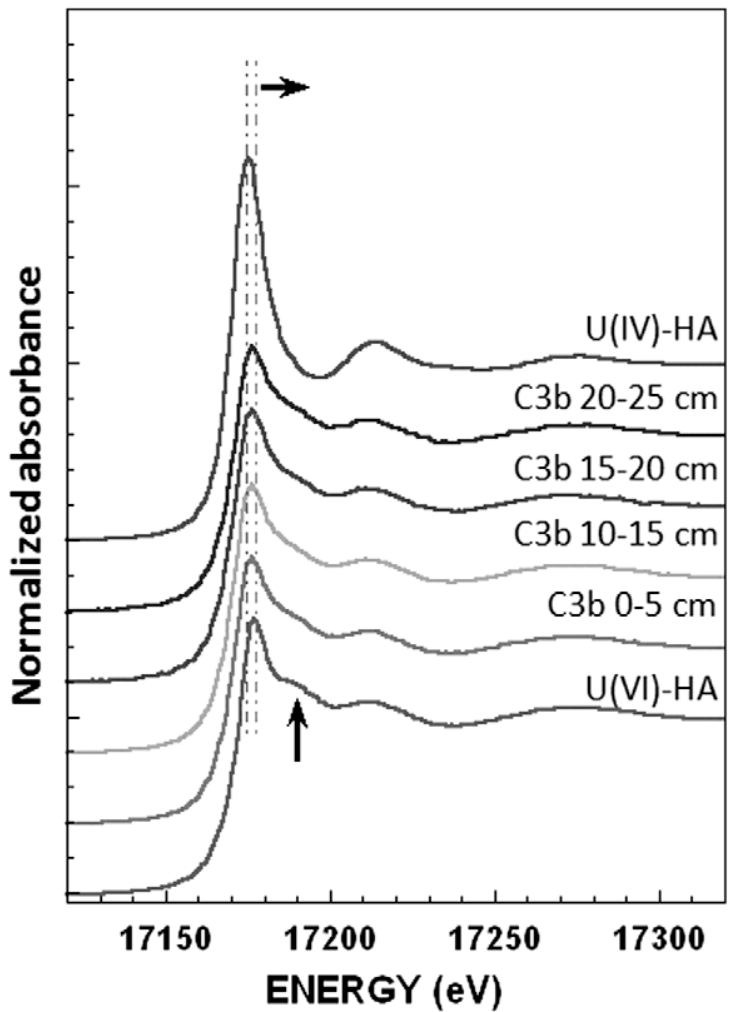

Fig. 9. Uranium $\mathrm{L}_{\mathrm{III}}$-edge XANES spectra of different core sample (C3b) in comparison with synthesized standards of known $\mathrm{U}$ redox state: $\mathrm{U}(\mathrm{IV})$ and $\mathrm{U}(\mathrm{VI})$ synthetic samples prepared in presence of humic acid (U(IV)-HA and U(VI)-HA, respectively). The vertical arrow indicates the shoulder associated with $\mathrm{U}(\mathrm{VI})$ and the horizontal arrow shows the slight edge shift characteristic of $\mathrm{U}(\mathrm{VI})$ as compared to U(IV). The Dischma samples fall in between the two lines indicating a mixture of valences.

dialysis cassettes containing Dischma OM resulted in a loss of $\mathrm{U}$ from the cassette both at oxic and anoxic conditions (Table 4) indicating that bicarbonate has a higher affinity for $\mathrm{U}$ than both oxidized and reduced Dischma OM.

\subsubsection{X-ray absorption spectroscopy}

3.2.4.1. XANES. The redox state of $\mathrm{U}$ in samples from different depths of soil core $\mathrm{C} 3 \mathrm{~b}$ was analyzed by X-ray

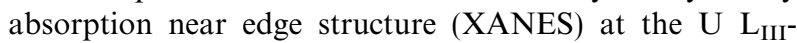
edge. The presence of the uranyl-characteristic shoulder at about $17,185 \mathrm{eV}$ was observed in all samples as well as in the U(VI)-HA standard (Fig. 9) strongly suggesting that $\mathrm{U}$ in core $\mathrm{C} 3 \mathrm{~b}$ occurs predominantly in the hexavalent state. The location of the white line slightly to lower energies in the samples relative to the $\mathrm{U}(\mathrm{VI})$ standard also points to the presence of some U(IV). Linear combination fits of Dischma soil XANES with spectra of a U(IV)-HA and a U(VI)-HA compound as references confirmed that $\mathrm{U}(\mathrm{VI})$ is the predominant redox state of $\mathrm{U}$ in the soils (Fig. 8).

3.2.4.2. EXAFS. Uranium $\mathrm{L}_{\mathrm{III}}$-edge EXAFS spectra $\left(\mathrm{k}^{3}\right.$ weighed) of the samples from $\mathrm{C} 3 \mathrm{~b}$ are displayed in Fig. 10 along with the corresponding Fourier transforms 

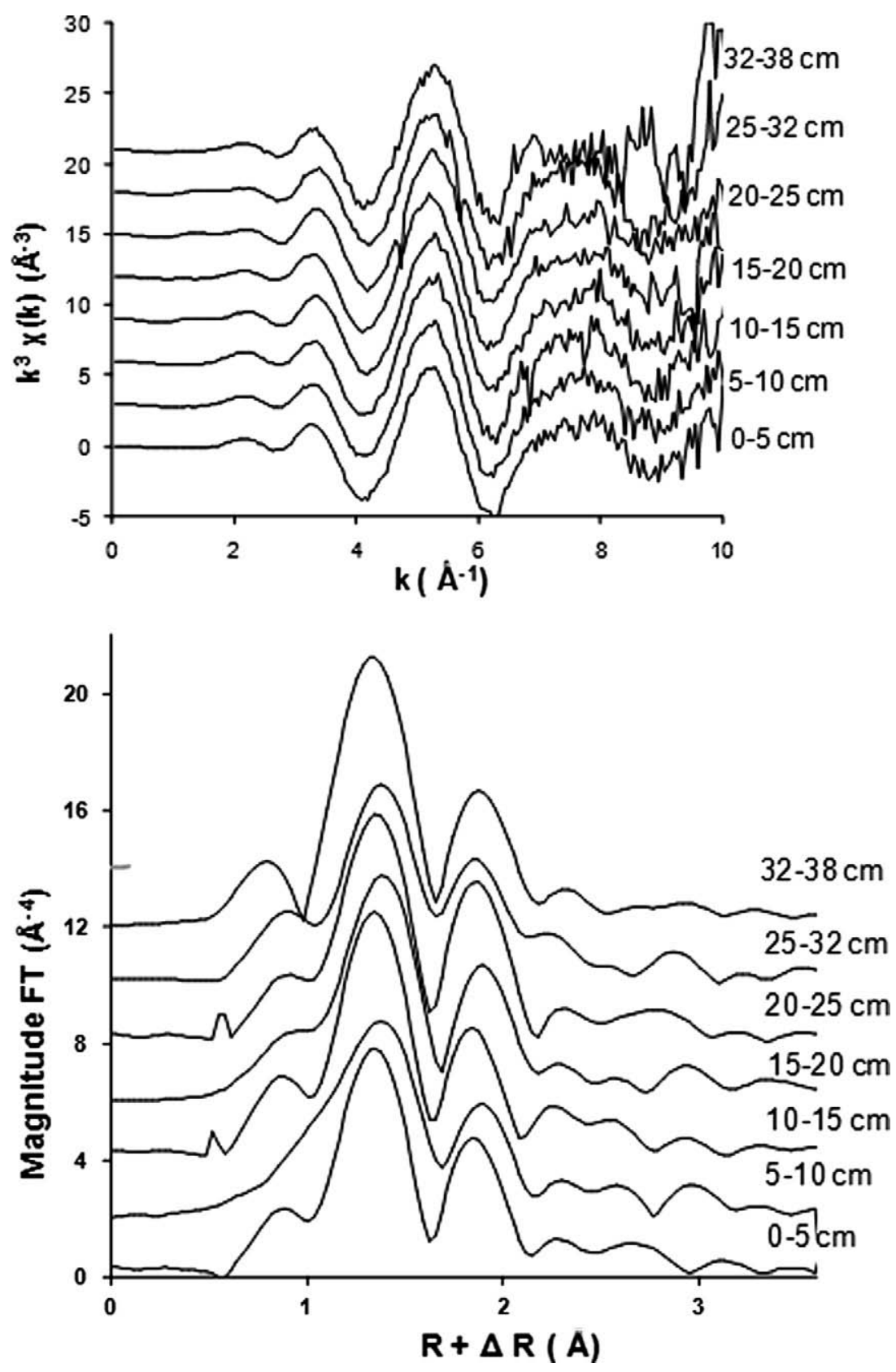

Fig. 10. Experimental $\mathrm{k}^{3}$-weighed uranium $\mathrm{L}_{\mathrm{III}}$ EXAFS for all core samples $\mathrm{C} 3 \mathrm{~b}$ (top) and their corresponding Fourier Transforms (bottom).

(FTs). Uranium concentration in core C3b ranged from 50 and $345 \mathrm{ppm}$ as measured by $\gamma$-spectroscopy. The EXAFS spectra are similar for all samples with a large oscillation between 3 and $6.5 \AA^{-1}$ followed by a small one from 6.5 to $9.5 \AA^{-1}$ for the various depths indicating that the binding of $U$ to the soil does not significantly vary with depth. A qualitative comparison of a sample EXAFS spectrum with those of standards - U(IV) as colloidal $\mathrm{UO}_{2}$ and $\mathrm{U}(\mathrm{VI})$ adsorbed to smectite - as well as a peat humic acid reacted with U(VI) or U(IV), is shown in Fig. 11. Qualitatively, it is readily apparent that the soil sample spectrum is significantly different from that of the $\mathrm{UO}_{2}$ species due to the absence of the U-U shell at about $3.73 \AA$ and to the shift of the first FT peak to higher $R$ that are typical of $\mathrm{UO}_{2}$ and $\mathrm{U}(\mathrm{IV})$, respectively. In contrast, the soil sample spectrum resembles that of the U(VI) humic acid standard, suggesting that $\mathrm{U}$ may be bound in a similar fashion to both the sample and the U(VI)-HA standard.

EXAFS spectra of the samples and the U(VI)-humic acid standard were fitted with parameters (coordination number $(\mathrm{CN})$ and inter-atomic distance $(R))$ obtained from several known U(IV) and U(VI) compounds (Loopstra et al., 1977; Viswanathan and Harneit, 1986; Miller and Taylor, 1986; Dusausoy et al., 1996; Finch et al., 1999; Locock et al., 2004). The first two shells of the FT spectra could be fitted reasonably well with parameters derived 

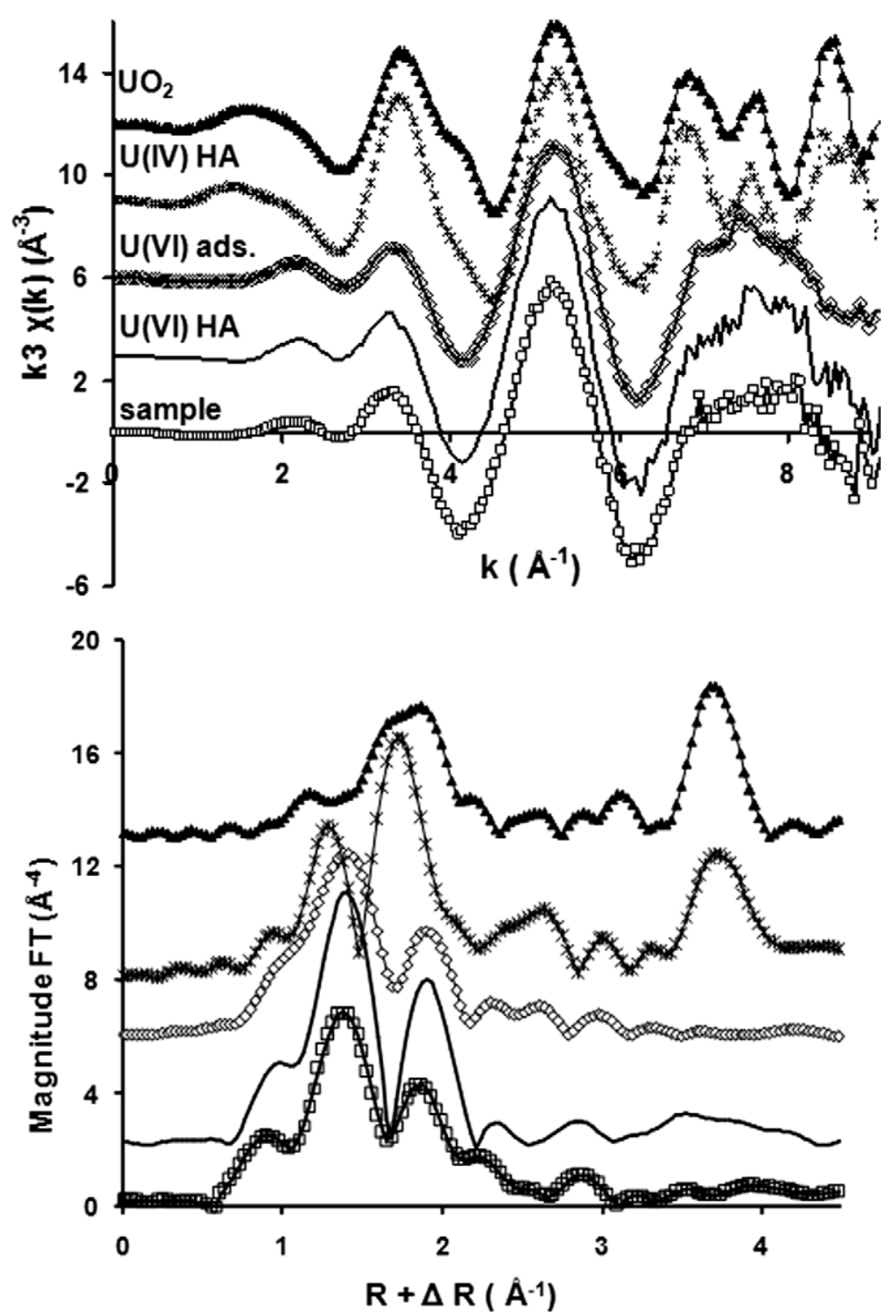

Fig. 11. Uranium $\mathrm{L}_{3}$-edge $\mathrm{k}^{3}$-weiged EXAFS data (top) and the corresponding Fourier transforms (bottom) of one core sample (C3b, collected at $20 \mathrm{~cm}$ depth; bottom spectra) compared to four references: colloidal $\mathrm{UO}_{2}\left(\mathrm{UO}_{2}\right.$, top), $\mathrm{U}(\mathrm{IV})$ humic acid standard (U(IV) $\mathrm{HA}$ ), $\mathrm{U}(\mathrm{VI})$ adsorbed to kaolinite (U(VI) ads), U(VI) humic acid standard (U(VI HA).

from U(VI) compounds (mainly $\beta$-uranophane $\left(\mathrm{Ca}\left(\mathrm{UO}_{2}\right)_{2}\right.$ $\left.\mathrm{SiO}_{3}(\mathrm{OH})_{2} \cdot 5\left(\mathrm{H}_{2} \mathrm{O}\right)\right)$ and uranyl carbonate $\left(\mathrm{UO}_{2} \mathrm{CO}_{3}\right)$ consisting of two-oxygen coordination shells. The first is a two-oxygen axial shell that typically has an inter-atomic distance of $1.79 \AA$. The second is a six-oxygen equatorial shell with inter-atomic distances ranging from 2.1 to $2.3 \AA$.

In the samples considered, $\mathrm{U}-\mathrm{O}_{\mathrm{ax}}$ distance was determined to be between 1.76 and $1.77 \AA$ with a $\mathrm{CN}$ varying between 1.6 and 1.8 atoms. The equatorial $\mathrm{U}-\mathrm{O}$ distance (U$\mathrm{O}_{\text {eq }}$ ) ranges from 2.33 to $-2.38 \AA$ with a $\mathrm{CN}$ between 5 and 6 atoms (Table 5, Fig. 12). The number of axial oxygen is a function of the $\mathrm{U}(\mathrm{VI}) / \mathrm{U}(\mathrm{IV})$ ratio in the samples indicating that $80-90 \%$ of $U$ exists in the uranyl-like hexavalent state (Fig. 8). Although the precision of the data can be influenced by certain factors, such as X-ray radiation, they correspond very well with results from XANES. They are also in the same range as results obtained by bicarbonate extrac- tion of the core C3a which was collected in close vicinity to C3b (Fig. 8).

Similarly, the U(VI)-reacted peat humic acid standard could be adequately fitted with the uranyl carbonate and $\beta$-uranophane models (Fig. 12). However, the equatorial oxygen atoms are at shorter distances as compared to the samples (Table 5). Moreover, in comparison to the soil samples spectra, the U(VI)-HA standard lacked significant peaks at distances greater than that of the second $\mathrm{U}-\mathrm{O}$ shell, suggesting that the soil samples contains an additional ligand not present in the standard. In order to fit this additional intermediate-range structure, sample spectra were fitted with several $U$ bearing structural models. The best fits were obtained by considering the contribution of two $\mathrm{Si}$ backscattering atoms at a distance of $3.14 \AA$ for samples close to the surface $(0-5 \mathrm{~cm})$. The U-Si shell distance is typical of a uranophane-like structure; however, the first oxy- 
Table 5

Structural EXAFS parameters (inter-atomic distances $(R)$, coordination number $(N), \sigma^{2}$ and $E_{0}$ of soil samples from core C3b in different depths as well as a soil extract at pH 9 from core C3a, and the U(VI) humic acid standard. The values in parentheses are the fit-derived onesigma uncertainties in the last reported digit.

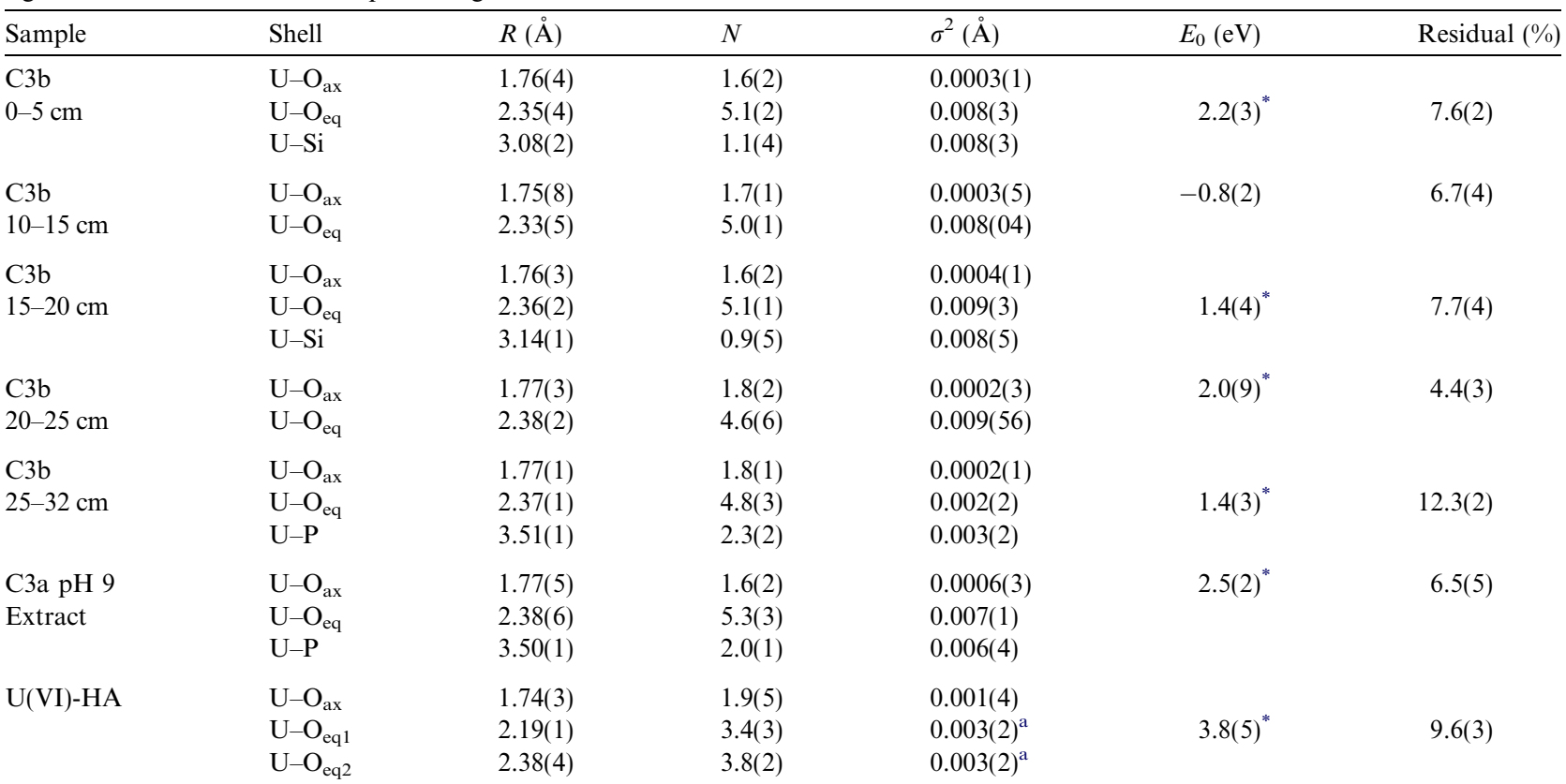

\footnotetext{
* All similar parameter correlated with.
}

a Parameters correlated for the same fit.

gen distances in the soil samples are shorter than the $\beta$ uranophane structure $(1.82 \AA$ and $2.40 \AA$, respectively, for $\mathrm{O}_{\mathrm{ax}}$ and $\left.\mathrm{O}_{\mathrm{eq}}\right)$. In contrast, spectra for deeper soil samples $(25-32 \mathrm{~cm})$ are best fitted by accounting for three phosphorus backscattering atoms at an inter-atomic distance U-P of about 3.50(1) $\AA$. Thus, $U$ in deep location in the soil $(25-32 \mathrm{~cm})$ present a structural behavior close $U$ phosphates such as $\mathrm{CaU}\left[\mathrm{PO}_{4}\right]_{2}, \mathrm{Mg}\left[\mathrm{UO}_{2} \mathrm{PO}_{4}\right]_{2}$, and $\mathrm{Na}\left[\mathrm{UO}_{2}\right.$ $\mathrm{PO}_{4}$ ]. No third shell fitting was possible for samples between the top and bottom layer of the profile (Table 5).

3.2.4.3. Micro $X A S$. A preliminary scan of a single soil sample $(\mathrm{C} 1)$ using micro-XAS shows that $U$ is not homogeneously distributed in the soil (map: supporting information, SI 4 in the electronic appendix). Clusters with higher $\mathrm{U}$ concentrations are surrounded by areas with lower U content.

\section{DISCUSSION}

The Dischma soil contains up to $4000 \mathrm{ppm} \mathrm{U}$ which is, to the best of our knowledge, the highest ever reported natural concentration of $\mathrm{U}$ in soil. It is known that elevated concentrations of $U$ occur in several geological units of the Alps, such as the metamorphic rocks of the Grisons, which are likely the primary source for observed $U$ anomalies (Mittempergher, 1972; Surbeck et al., 2006). The isotopic composition of $U$ in Dischma soils indicates that it originates from natural sources. In addition, the separation of $U$ from its daughter isotopes in the Dischma soils points to the leaching of $U$ by ground or surface water from a source rock. Indeed, streams and seepage feeding the sampling areas contained small but measurable concentrations of $\mathrm{U}(0.12-0.39 \mu \mathrm{M})$ and about $10 \mathrm{nM} \mathrm{U}$ was measured in the Dischma River. Additionally, an extensive survey of $U$ content in ground and surface water in the Canton Grisons (Deflorin, 2004) revealed widespread presence of low $U$ concentrations throughout the region. The investigators suggest that weathering processes release $U$ from alpine crystalline rocks containing trace amounts of this radionuclide (Deflorin, 2004). We assume that these low amounts could be retained and accumulated in the valley soils by mechanisms discussed in the following.

In our study, we tackled the question of the nature of $U$ binding to the soil including its speciation and oxidation state. The two plausible mechanisms which might be responsible for $\mathrm{U}$ immobilization and enrichment are reduction of $\mathrm{U}(\mathrm{VI})$ to $\mathrm{U}(\mathrm{IV})$ followed by precipitation of $\mathrm{UO}_{2}$ (which could be expected due to reducing soil conditions) or the complexation of U(VI) with ligands. Because of the high U content found in the Dischma soil, we were able to carry out $\mathrm{X}$-ray absorption spectroscopic (XAS) measurements on soil samples, which allowed us to obtain structural information about the $\mathrm{U}$ binding in the soil. This is the first time that $\mathrm{UL}_{\mathrm{III}}$ XAS analysis was conducted on field samples derived from a site undisturbed by anthropogenic inputs.

\subsection{Redox state of uranium in Dischma soil}

The porewater profile of the Dischma soil shows decreasing sulfate and increasing $\mathrm{Fe}(\mathrm{II})$ concentrations as a function of depth (Fig. 2) hence suggesting that below a 


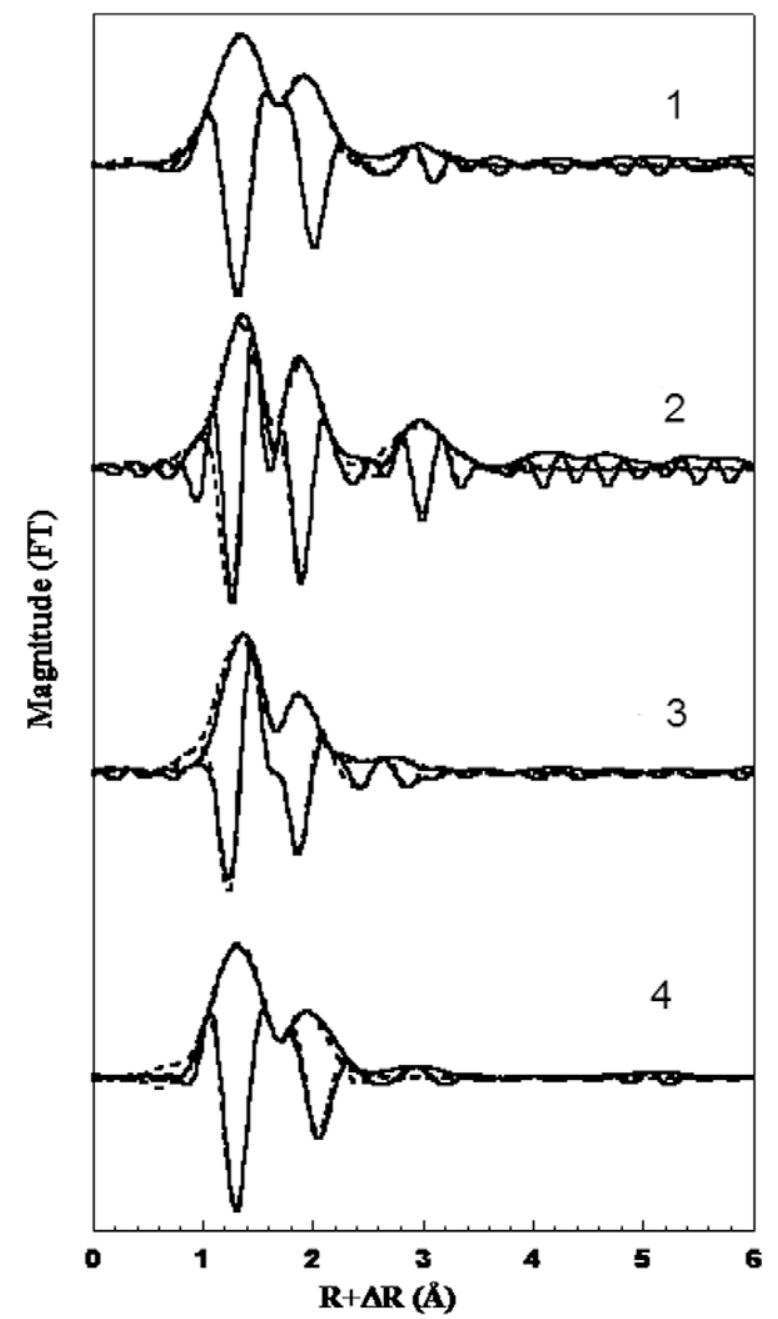

Fig. 12. Uranium L3-edge Fourier transforms EXAFS data and fit. Solid lines represent data; dashed lines represent fits. (1) C3a soil sample $(17 \mathrm{~cm})$ extract at $\mathrm{pH}$ 9, fit with $\mathrm{UO}_{3 \text {. (2) }} \mathrm{C} 3 \mathrm{~b}$ sample of the profile $(25-32 \mathrm{~cm})$, fit with $\mathrm{U}(\mathrm{VI})$ phosphate. (3) C3b top sample of the profile $(0-5 \mathrm{~cm})$, fit with $\mathrm{U}(\mathrm{VI})$ silicate. (4) U(VI) humic acid standard and fit with $\mathrm{UO}_{3}$.

certain depth (about $15 \mathrm{~cm}$; Fig. 2) reducing conditions are established. In addition, microbiological investigations indicate that the sulfate- and iron-reducing bacteria present in the soil are able to reduce $\mathrm{U}(\mathrm{VI})$ to $\mathrm{U}(\mathrm{IV}$ ) (data not shown) through direct (= enzymatic) and indirect redox processes (Wall and Krumholz, 2006). Thus, U(VI) reduction can be expected in this environment. Several methods were applied to identify the oxidation state of $U$ in the soil.

Bicarbonate extraction was used successfully in previous studies to quantitatively distinguish between U(VI) and U(IV) (Zhou and Gu, 2005; Burgos et al., 2007). The results obtained in our study indicated that most of the U (51$100 \%$ ) was present as U(VI) in the soil (Fig 8). This was confirmed by XANES spectra due to a shift of the white line of sample spectra to higher energies relative to the U(IV) standards and to the appearance of the uranyl-characteristic shoulder in the spectra (Fig. 9). Linear combination fitting of the XANES spectra shows that $U$ in core
$\mathrm{C} 3 \mathrm{~b}$ is a mixture of $\mathrm{U}$ redox states which consists mainly $(>81 \%)$ of $\mathrm{U}(\mathrm{VI})$ (Figs. 8 and 9). While there is more variation in the fraction of U(IV) as a function of depth for the bicarbonate extraction $(0-49 \%)$ than for the XANES $(0$ $19 \%$ ), the two measurements were obtained from separate cores (C3a and C3b). Similarly, U redox states of two cores ( $\mathrm{C} 1$ and $\mathrm{C} 3 \mathrm{a}$ ) treated in the same way (by bicarbonate extraction) but collected from different sampling areas vary even more significantly (Figs. 1 and 8). In general, U concentration and speciation show a high degree of heterogeneity as it was encountered repeatedly throughout our sampling area which is readily apparent in Figs. 1 and 8.

Analysis of EXAFS data obtained as a function of depth in core $\mathrm{C} 3 \mathrm{~b}$ confirms the findings presented above. The first two shells can be fitted with parameters from any octahedral U(VI) compound in which $\mathrm{U}$ displays two axial oxygens at about $1.76 \pm 0.01 \AA$ and five to six equatorial oxygens at about $2.35 \pm 0.03 \AA$ (Table 5). This result suggests that U EXAFS in the soil are dominated by those two shells, which are characteristic of the hexavalent $U$ cation, uranyl. Interestingly, there is no evidence of a $\mathrm{U}-\mathrm{U}$ shell at $3.76 \AA$ A, which is commonly considered to be typical of the presence of the tetravalent $\mathrm{U}$ mineral $\mathrm{UO}_{2}$ (Schofield et al., 2008). However, the absence of a distinct U-O shell at about $2.35 \AA$ that is typical of the U(IV) oxygen shell does not preclude its presence. It is simply too close to the $\mathrm{U}(\mathrm{VI})-\mathrm{O}_{\mathrm{eq}}$ shell for the fitting to distinguish between the two. Thus, the EXAFS fits are compatible with the presence of a mixture of U(VI) and U(IV) with U(VI) being more prevalent. The absence of the U-U shell clearly shows that $\mathrm{U}(\mathrm{IV})$ is not present as mineral uraninite $\left(\mathrm{UO}_{2}\right)$, which would be the expected form of reduced $U$ in the environment (Abdelouas et al., 2000). However, sorbed forms of U(IV) have been reported previously (Kelly et al., 2008). Since only relatively small amounts of U(IV) were found in the soil despite reducing conditions at higher depths, we suggest that the binding of U(VI) to solid organic matter might prevent its (biological) reduction. This was suggested by Burgos et al. (2007) and Haas and Northup (2004) who found that abundant organic matter inhibits $\mathrm{U}(\mathrm{VI})$ reduction by microorganisms presumably due to the change in redox potential associated with the complexation of $\mathrm{U}(\mathrm{VI})$ or to the kinetically limited release of U(VI) from the complexes.

\subsection{U binding to Dischma soils}

There is ample evidence of the association of $U$ with organic matter in Dischma soil. First, $U$ concentrations across the valley show a substantial association with TOC content (Fig. 4a). Furthermore, U content is also correlated to TOC content as a function of depth in soil cores (Fig. 4b). These (qualitative) indications of $U$ - organic matter association were confirmed quantitatively by sequential extraction. In this experiment, the majority (95-98\% of total) of soil $U$ was released by oxidation by $\mathrm{NaOCl}$, which is known to oxidize organic matter efficiently. The simultaneous dissolution of $U$ and $\mathrm{OM}$ suggests the association of the two compounds. Further evidence supporting $\mathrm{U}$ binding to $\mathrm{OM}$ is provided by the 
concomitant release of organic carbon and $\mathrm{U}$ after treatment of the soil at pH 5, 7 and 9 (Fig. 7). At neutral and alkaline $\mathrm{pH}$ values, both organic carbon and $\mathrm{U}$ are released from the soil, suggesting a direct association of the two compounds. Finally, U(VI) (added as uranyl cation) is retained in a dialysis cassette by binding to high molecular weight aqueous Dischma organic matter obtained by $\mathrm{pH}$ 9 treatment of the soil (Table 4). This result suggests that Dischma OM has a very high affinity for U. In contrast, $\mathrm{U}(\mathrm{VI})$ diffuses out of the cassette in the presence of bicarbonate that outcompetes $\mathrm{OM}$ for $\mathrm{U}$ or in the absence of aqueous organic matter (Table 4).

The presence of high $U$ concentrations in histosols or wetlands has been reported previously (e.g., Gonzalez et al., 2006, up to $600 \mathrm{ppm}$; Owen and Otton, 1995, up to $3000 \mathrm{ppm})$. In the majority of the cases, $U$ mines or mine tailings (Pfeifer et al., 1994; Owen and Otton, 1995; Schöner et al., 2008; Sobolewski, 1999), or phosphate fertilizers (Zielinski et al., 2006) were main sources for U input. However, another study considers a similar situation by which high $\mathrm{U}$ enrichment (up to $1000 \mathrm{ppm}$ ) occurs in a peat bog (which is located close to a natural $\mathrm{U}$ mineralization), where it is accumulated due to complexation and retention by carboxyl functional groups (Read et al., 1993). Similarly, Vandenhove et al. (2006) found a strong positive correlation between $U$ and soil organic matter when introducing $\mathrm{U}(\mathrm{VI})$ into different types of soil samples indicating that $\mathrm{U}$ binds to the organic matter.

However, none of the above-mentioned studies sought spectroscopic evidence to support hypotheses on the nature of $U$ binding to soils. Because of the very high natural $U$ concentrations present in Dischma, we were able to perform EXAFS measurements and obtain information on the structural U coordination. The comparison of EXAFS spectra of the samples and standards (Figs. 10 and 11) revealed that soil samples and the U(VI) humic acid standard have similar $U$ coordination. While the first two shells of the EXAFS spectra suggest that U occurs as a uranyl compound (Table 5), the third shell could be an indicator of the binding environment of $\mathrm{UO}_{2}{ }^{+}$.

Even before considering the third shell, the $\mathrm{U}-\mathrm{O}_{\text {eq }}$ shell distance suggests that uranyl is bound within organic complexes. In Moll et al. (2003), the $\mathrm{U}-\mathrm{O}_{\mathrm{eq}}$ distance was found to decrease with increasing $\mathrm{pH}(2.43 \AA$ at $\mathrm{pH} 2-4$ and $2.36 \AA$ at $\mathrm{pH}>5$ ) when uranyl was equilibrated with glyconate or hydroxybutyrate (Table 6). This observation was interpreted as a strong indication of the formation of a (chelate) complex between uranyl and either organic com- pound and the shortening of the bond attributed to the binding of the equatorial oxygen at the alpha hydroxyl position in ligand. Thus, the similarly short $\mathrm{U}-\mathrm{O}_{\text {eq }}$ distance identified in the Dischma samples (Tables 5 and 6) is consistent with association of $\mathrm{U}(\mathrm{VI})$ with organic compounds.

A weak third shell at about $3 \AA$ (uncorrected $R+\partial R$ on the FT spectra) indicated that $U$ is bound to a light element such as phosphorus, sulfur, silicon or carbon (for which we expect inter-atomic distances with $\mathrm{U}$ between 3.0 and $3.6 \AA$ ) that usually show only a weak spectral contribution when measured at the $\mathrm{U} \mathrm{L}_{\mathrm{III}}$-edge because they are weak photoelectron backscatterers (Thompson et al., 1997). Coordination of $U$ with organic substances was investigated by EXAFS in several studies (e.g., Denecke et al., 1998; Moll et al., 2003), but the complexes considered typically involve well defined organic model compounds with limited and known functional groups such as triacetatodioxouranium(VI) $\left(\mathrm{NaUO}_{2}\left(\left(\mathrm{CH}_{3} \mathrm{COOH}\right)_{3}\right)\right.$ or U(VI) glycolate (Table $6)$. In the above-mentioned studies, $\mathrm{U}-\mathrm{C}$ binding characteristics were determined and the U-C distance found to vary between 2.8 and $3.2 \AA$ depending on the organic compound and the $\mathrm{pH}$ value. This $\mathrm{U}-\mathrm{C}$ shell was interpreted to represent bidentate coordination of carboxylate ions to uranyl (Table 6; Denecke et al., 1998). In contrast, natural organic matter is a mixture of many organic compounds with numerous and uncharacterized functional groups. Schmeide et al. (2003) investigated complexes between humic acid and U(VI) by XAS but the fits focused only on the first two coordination shells presumably due to difficulties in fitting higher shells. Because humic acid contains numerous functional groups such as carboxylic and phenolic groups, destructive interference among the shells could account for the minimal intermediate-range structure observed. Thus, in the Dischma samples, we did not identify specific coordination to $\mathrm{C}$ moieties but we found $R$ values for the third shell ( 3.08 and $3.14 \AA$ ) that were consistent with $\mathrm{Si}$ and $(3.50(1) \AA$ ) with $\mathrm{P}$ indicating the presence of light elements around $\mathrm{U}$ complexes (Fig. 12). These $R$ values are not consistent with binding of U(VI) to mineral surfaces such as goethite or clays precluding the presence of such species in significant concentrations (Redden et al., 2001; Hennig et al., 2002).

Phosphate is known to complex organic material (e.g., Paludan and Jensen, 1995) and some phosphate was found in the soils (up to $28 \mu \mathrm{mol} / \mathrm{g}$; Fig. 5) and in the porewater (1.6-7.1 $\mu \mathrm{mol} / \mathrm{L}$ in PW3). A possible explanation for the presence of a $\mathrm{P}$ shell in these organic-rich samples is the formation of ternary complexes by which the positively

Table 6

Comparison of $\mathrm{U}-\mathrm{O}$ distances (axial and equatorial) and $\mathrm{U}-\mathrm{C}$ obtained in from several literature studies.

\begin{tabular}{lllll}
\hline & $\mathrm{U}-\mathrm{O}_{\mathrm{ax}}(\AA)$ & $\mathrm{U}-\mathrm{O}_{\text {eq }}(\AA)$ & $\mathrm{U}-\mathrm{C}(\AA)$ & References \\
\hline $\mathrm{UO} 2(\mathrm{Gly})_{2}{ }^{2-}, \mathrm{pH} 8$ & 1.80 & 2.37 & 3.25 & Moll et al. (2003) \\
$\mathrm{U}(\mathrm{VI})$ in hydroxy-butric acid, $\mathrm{pH} 4$ & 1.78 & 2.45 & 2.84 & Moll et al. (2003) \\
$\mathrm{UO}_{2} \mathrm{CO}_{3}$ & 1.74 & 2.44 & 2.93 & Finch et al. (1999) \\
$\mathrm{NaUO}_{2}\left(\left(\mathrm{CH}_{3} \mathrm{COOH}\right)_{3}\right)$ & $1.76-1.78$ & $2.29-2.48$ & 2.89 & Denecke et al. (1998) \\
$\mathrm{UO}_{2}\left(\mathrm{C}_{6} \mathrm{H}_{5}(\mathrm{COO})\right)_{2}$ & 1.77 & $2.29-2.42$ & 2.86 & Denecke et al. (1998) \\
$\mathrm{UO}_{2}{ }^{2+}$ & 1.76 & 2.40 & & Moll et al. (2003) \\
$\mathrm{U}(\mathrm{VI})$ humic acid & 1.78 & 2.39 & & Schmeide et al. (2003) \\
\hline
\end{tabular}


charged uranyl bridges the negatively charged phosphate and the predominantly negatively charged groups of the organic material. The existence of such complexes was previously suggested by Paludan and Jensen (1995) and Schnitzer and Khan (1972). However, the technique brought to bear on this problem (i.e., U EXAFS) does not allow the detailed investigation of the structure of such complexes in Dischma soil. A preliminary micro-XAS analysis of these samples (SI Fig. 4) indicated a heterogeneous distribution of $U$ with areas of high $U$ concentrations (hotspots) as well as a diffuse $U$ background supporting the hypothesis that several species may be present. Further micro-XAS investigations are planned in the future.

\section{CONCLUSIONS}

We found that $U$ from natural sources accumulates in the Dischma soil and originates away from the soil itself suggesting transport by water. Various experiments revealed that $\mathrm{U}$ was bound to soil organic matter rather than to mineral phases and was present primarily in the hexavalent state. Some fraction was also present as tetravalent $U$ which occurs as different structure as the mineral $\mathrm{UO}_{2}$. We conclude that $\mathrm{U}$ is directly bound to the soil organic matter with a possible contributing species being an organophosphate/silica complex. The U enrichment in the Dischma valley could be construed as an environmental risk because a change in soil water conditions (e.g., by the application of fertilizers or the drainage of the peat soil for agricultural purposes) might lead to the release of currently bound $\mathrm{U}$.

\section{ACKNOWLEDGMENTS}

We gratefully acknowledge Harish Veeramani and Nick Wiggington from the Environmental Microbiology Laboratory at EPFL for help running samples at the SLS beamline. Also we want to acknowledge Andreas Scheinost (Forschungszentrum DresdenRossendorf, FZD) for providing XAS data of U standards. For analytical support we thank Felippe de Alencastro for providing lab facilities of CEL (EPFL) and Jean-David Teuscher for various measurements. We also acknowledge Francesca Gambazi, Fabienne Luisier, and Manon Frutschi (EPFL) for assistance during field trips and various measurements. XRD measurements were performed by Thierry Adatte from the Geological Institute of the University of Neuchâtel. Special thanks also to Camelia Borca (SLS, PSI) for preliminary measurements at the micro XAS beamline at the SLS and to Christian Ludwig (EPFL, PSI) for supporting the project in all respects.

\section{APPENDIX A. SUPPLEMENTARY DATA}

Supplementary data associated with this article can be found, in the online version, at doi:10.1016/j.gca.2010. 01.007 .

\section{REFERENCES}

Abdelouas A., Lutze W., Gong W. L., Nuttall E. H., Strietelmeier B. A. and Travis B. J. (2000) Biological reduction of uranium in groundwater and subsurface soil. Sci. Total Environ. 250(1-3), $21-35$.
Adatte T., Stinnesbeck W. and Keller G. (1996) Lithostratigraphic and mineralogical correlations of near- $\mathrm{K} / \mathrm{T}$ boundary clastic sediments in northeastern Mexico: implications for megatsunami or sea level changes? Geol. Soc. Am. Spec. Pap. 307, 197-210.

Allen P. G., Shuh D. K., Bucher J. J., Edelstein N. M., Palmer C. E. A., Silva R. J., Nguyen S. N., Marquez L. N. and Hudson E. A. (1996) Determinations of uranium structures by EXAFS: schoepite and other U(VI) oxide precipitates. Radiochim. Acta 75, 47-53.

APWA (American Public Works Association) (1998) Standard Methods for the Examination of Water and Wastewater, 20th ed. American Water Works Association, Water Environment Federation, 6666 West Quincy Avenue, Denver, Colorado 80235.

Ames B. N. (1966) Assay of Inorganic Phosphate, Total Phosphate and Phosphatase B.N. Ames, Assay of inorganic phosphate, total phosphate and phosphatases. In Methods in Enzymology, vol. 8 (eds. E. F. Neufield and V. Ginsburg). Academic Press, New York, London, pp. 115-118.

Bernhard G. (2005) Speciation of uranium in environmental relevant compartments. Landbauforsch. Volk. 55(3), 139-148.

Blodau C., Bauer M., Regenspurg S. and Macalady D. (2009) Electron accepting capacity of dissolved organic matter as determined by reaction with metallic zinc. Chem. Geol. 260, 186-195.

Burgos W. D., Senko J. M., Dempsey B. A., Roden E. E., Stone J. J., Kemner K. M. and Kelly S. D. (2007) Soil humic acid decreases biological uranium(VI) reduction by Shewanella putrefaciens CN32. Environ. Eng. Sci. 24(6), 755-761.

Buttler A., Grosvernier P. and Matthey Y. (1998) A new sampler for extracting undisturbed surface peat cores for growth pot experiments. New Phytol. 140, 335-360.

Deflorin O. (2004). Natürliche Radionuklide in Grundwässern des Kantons Graubünden, $\mathrm{PhD}$ thesis, Univ. de Neuchâtel.

Denecke M. A., Reich T., Bubner M., Pompe S., Heise K. H., Nitsche H., Allen P. G., Bucher J. J., Edelstein N. M. and Shuh D. K. (1998) Determination of structural parameters of uranyl ions complexed with organic acids using EXAFS. J. Alloy Compd. 271, 123-127.

Dusausoy Y., Ghermanin N. E., Podor R. and Cuney M. (1996) Low-temperature ordered phase of $\mathrm{Ca} \mathrm{U}$ (PO4)2. Synthesis and crystal structure. Eur. J. Min. 8, 667-673.

Finch R. J., Cooper M. A., Hawthorne F. C. and Ewing R. C. (1999) Refinement of the crystal structure of rutherfordine. Can. Mineral. 37, 929-938.

Fritz J. S. and Gjerde D. T. (2009) Ion Chromatography. WileyVCH Verlag, Weinheim, Germany.

Gonzalez Z. I., Krachler M., Cheburkin A. K. and Shotyk W. (2006) Spatial distribution of natural enrichments of arsenic, selenium, and uranium in a minerotrophic peatland, Gola di Lago, Canton Ticino, Switzerland. Environ. Sci. Technol. 40(21), 6568-6574.

Grybos M., Davranche M., Gruau G. and Petitjean P. (2007) Is trace metal release in wetland soils controlled by organic matter mobility or Fe-oxyhydroxides reduction? J. Colloid Interf. Sci. 314(2), 490-501.

Gu B. and Chen J. (2003) Enhanced microbial reduction of Cr(VI) and $\mathrm{U}(\mathrm{VI})$ by different natural organic matter fractions. Geochim. Cosmochim. Acta 67(19), 3575-3582.

Gu B., Yan H., Zhou P., Watson D. B., Park M. and Istok J. (2005) Natural humic impact uranium bioreduction and oxidation. Environ. Sci. Technol. 30(14), 5268-5275.

Haas J. R. and Northup A. (2004) Effects of aqueous complexation on reductive precipitation of uranium by Shewanella putrefaciens. Geochem. T. 5(3), 41-48. 
Hennig C., Reich T., Dahn R. and Scheidegger A. M. (2002) Structure of uranium sorption complexes at montmorillonite edge sites. Radiochim. Acta 90(9-11), 653-657.

Hudson E. A., Allen P. G. and Terminello L. J. (1996) Polarized Xray absorption spectroscopy of the uranyl ion: comparison of experiment and theory. Phys. Rev. B. 54, 156-165.

Kelly S. D., Kemner K. M., Carley J., Criddle C., Jardine P. M., Marsh T. L., Phillips D., Watson D. and Wu W. M. (2008) Speciation of uranium in sediments before and after in situ biostimulation. Environ. Sci. Technol. 42(5), 1558-1564.

Langmuir D. (1978) Uranium solution-mineral equilibria at low temperatures with applications to sedimentary ore deposits. Geochim. Cosmochim. Acta 42, 547-569.

Locock A. J., Burns P. C., Duke M. J. M. and Flynn T. M. (2004) Monovalent cations in structures of the meta autunite group. Can. Mineral. 42, 973-996.

Loopstra B. O., Taylor J. C. and Waugh A. B. (1977) Neutron powder profile studies of the gamma uranium trioxide phases. J. Solid State Chem. 20, 9-19.

Lovley D. R., Blunt-Harris E. L., Phillips E. J. P. and Woodward J. C. (1996) Humic substances as electron acceptors for microbial respiration. Nature 382, 445-448.

Lutz H. (2002) Detoxification of filter ashes from waste incinerators, Ph.D. Thesis No 14653, ETH.

Miller S. A. and Taylor J. C. (1986) The crystal structure of selenite, $\mathrm{Mg}\left(\mathrm{UO}_{2} \mathrm{PO}_{4}\right)_{2} * 10 \mathrm{H}_{2} \mathrm{O}$. Z. Kristallogr. 177(3-4), 247253.

Mittempergher M. (1972) The paleogeographical, lithological and structural controls of uranium occurrences in the Alps. Geologija 15, 63-76.

Moll H., Geipel G., Reich T., Bernhard G., Fanghanel T. and Grenthe I. (2003) Uranyl(VI) complexes with alpha-substituted carboxylic acids in aqueous solution. Radiochim. Acta 91(1), $11-20$.

Newville M. (2001) IFEFFIT: Interactive EXAFS analysis and FEFF fitting. J. Synch. Rad. 8, 322-324.

Owen D. E. and Otton J. K. (1995) Mountain wetlands: efficient uranium filters-potential impacts. Ecol. Eng. 5, 77-93.

Paludan C. and Jensen H. S. (1995) Sequential extraction of phosphorus in freshwater wetland and lake sediment: significance of humic acids. Wetlands 15(4), 365-373.

Pfeifer H.-R., Vust M., Meisser N., Doppenberg R., Croci Torti R., Domergue F.-L., Keller C. and Hunziker J. (1994) Uranium contamination of soils and plants in the vicinity of a pitchblende vein at La Creusaz/Les Marécottes (Wallis). Eclogae Geol. Helv. 87, 491-501.

Read D., Bennett D. G., Hooker P. J., Ivanovich M., Longworth G., Mildowski A. E. and Noy D. J. (1993) The migration of uranium into peat-rich soils at Broubster, Caithness, Scotland, UK. J. Contam. Hydrol. 13, 291-308.

Redden G. R., Bargar J. R. and Bencheikh-Latmani R. (2001) Citrate enhanced uranyl adsorption to goethite: an EXAFS analysis. J. Colloid Interface Sci. 244(1), 211-219.

Rehr J. J., Mustre de Leon J., Zabinsky S. I. and Albers R. C. (1991) Theoretical X-ray absorption fine structure standards. $J$. Am. Chem. Soc. 113, 5135.

Ressler T. (1998) WinXAS: a program for X-ray absorption spectroscopy data analysis under MS-Windows. J. Synchrotron Radiat. 5, 118-122.

Sa Bochud. F., Bochud F., Laedermann J. P., Njock M. G. K. and Froidevaux P. A. (2008) Comparison of alpha and gamma spectrometry for environmental natural radioactivity surveys. Appl. Radiat.Isotopes 66(2), 215-222.

Schmeide K., Sachs S., Bubner M., Reich T., Heise K. H. and Bernhard G. (2003) Interaction of uranium(VI) with various modified and unmodified natural and synthetic humic sub- stances studied by EXAFS and FTIR spectroscopy. Inorg. Chim. Acta 351, 133-140.

Schnitzer M. and Khan S. U. (1972) Humic substances in the environment. Marcel Dekker, New York, pp. 57-60.

Schofield E. J., Veeramani H., Sharp J. O., Suvorova E., BernierLatmani R., Mehta A., Stahlmann J., Webb S. M., Clark D. L., Mehta A. J., Conradson S. D., Ilton E. S. and Bargar J. R. (2008) Structure of biogenic uraninite produced by Shewanella oneidensis strain MR-1. Environ. Sci. Technol. 42(21), 7898 7904.

Schultz M. K., Burnett W., Inn K. G. W. and Smith G. (1998) Geochemical partitioning of actinides using sequential chemical extractions: Comparison to stable elements. J. Radioanal. Nucl. Chem. 234(1-2), 251-256.

Schöner A., Noubactep C., Büchel G. and Sauter M. (2008) Geochemistry of natural wetlands in former uranium milling sites (eastern Germany) and implications for uranium retention. Chem. Erde-Geochem., 1-17.

Scott D. T., McKnight D. M., Blunt-Harris E. L., Kolesar S. E. and Lovley D. R. (1998) Quinone moieties act as electron acceptors in the reduction of humic substances by humicsreducing microorganisms. Environ. Sci. Technol. 32(19), 2984 2989.

Sobolewski A. (1999) A review of processes responsible for metal removal in wetlands treating contaminated mine drainage. Int. J. Phytoremediat. 1(1), 19-51.

Sørensen J. (1982) Reduction of ferric iron in anaerobic, marine sediment and interaction with reduction of nitrate and sulfate. Appl. Environ. Microbiol. 43, 319-324.

Steinmann P. and Shotyk W. (1997) Chemical composition, pH, and redox state of sulfur and iron in complete vertical porewater profiles from two Sphagnum peat bogs, Jura Mountains, Switzerland. Source:. Geochim. Cosmochim. Acta 61(6), 1143-1163.

Stumm W. and Morgan J. J. (1996) Aquatic Chemistry - Chemical equilibria and rates in natural waters. Wiley-Interscience, $\mathrm{p}$. 1024.

Stuyk Z. and Sposito G. (2001) Redox properties of standard humic acids. Geoderma 102, 329-346.

Surbeck H., Deflorin O. and Kloos O. (2006) Spatial and temporal variations in the uranium series background in Alpine groundwaters. In Uranium in the Environment, Mining Impact, Consequences (eds. B. J. Merkel and A. Hasche-Berger). SpringerVerlag, Berlin, Heidelberg, pp. 831-839.

Thompson H. A., Brown G. E. and Parks G. A. (1997) XAFS spectroscopic study of uranyl coordination in solids and aqueous solution. Am. Mineral. 82(5-10), 483-496.

Vandenhove H., Van Hees M., Wouters K. and Wannijn J. (2006) Can we predict uranium bioavailability based on soil parameters? Part 1: effect of soil parameters on soil solution uranium concentration. Environ. Pollut. 145(2), 587-595.

Viswanathan K. and Harneit O. (1986) Refined crystal structure of beta-uranophane, $\mathrm{Ca}\left(\mathrm{UO}_{2}\right)_{2}\left(\mathrm{SiO}_{3} \mathrm{OH}\right)_{2} \cdot{ }_{5} \mathrm{H}_{2} \mathrm{O}$. Am. Mineral. 71, 1489-1493.

Wall J. D. and Krumholz L. R. (2006) Uranium reduction. Annu. Rev. Microbiol. 60, 149-166.

Zhou P. and Gu B. (2005) Extraction of oxidized and reduced forms of uranium from contaminated soils: effects of carbonate concentration and pH. Environ. Sci. Technol. 39(12), 4435-4440.

Zielinski R. A., Orem W. H., Simmons K. R. and Bohlen P. J. (2006) Fertilizer-derived uranium and sulfur in rangeland soil and runoff: A case study in central Florida. Water Air Soil Polut. 176, 163-183. 